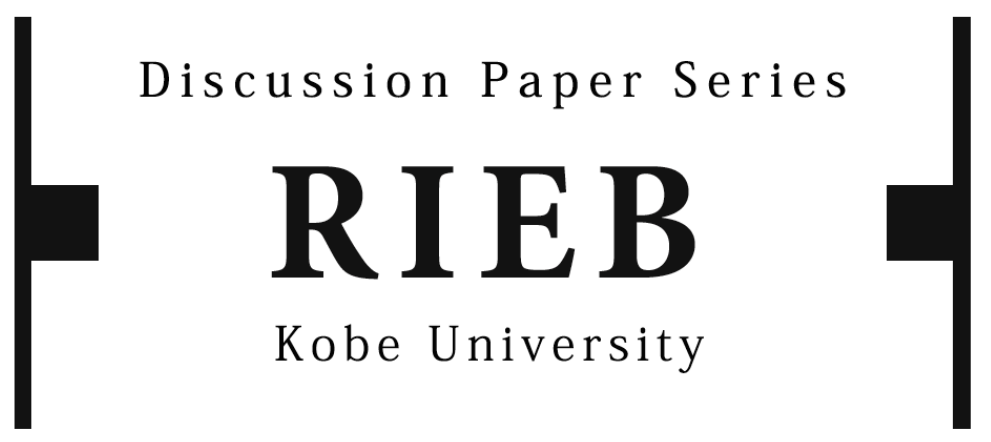

DP2018-20

\title{
Does the Old Age Pension Scheme Improve Household Welfare? Evidence from India
}

\section{Vidhya UNNIKRISHNAN}

Katsushi S. IMAI

Revised May 11, 2020

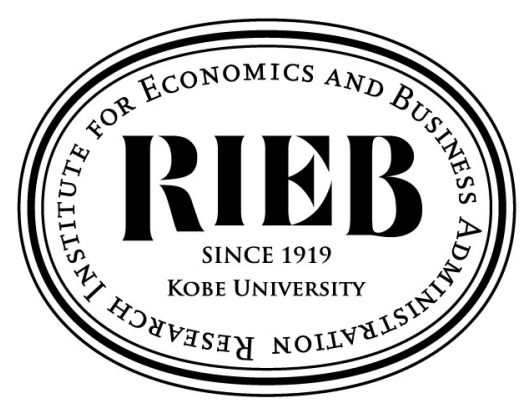

Research Institute for Economics and Business Administration Kobe University 


\title{
Does the old age pension scheme improve household welfare? Evidence from India
}

\author{
Vidhya Unnikrishnan* and Katsushi S. Imai†€ \\ *Global Development Institute, The University of Manchester, UK \\ $\uparrow$ Department of Economics, The University of Manchester, UK \\ $€$ RIEB, Kobe University, Japan \\ This Draft: $9^{\text {th }}$ May 2020
}

\begin{abstract}
As India's population has been ageing due to declines in fertility and mortality rates, more policy emphasis has been placed on reducing poverty among the elderly. The present study aims to examine the effect of Indira Gandhi National Old Age Pension Scheme (IGNOAPS) on household welfare indicators, such as consumption expenditure, income, assets, and poverty. Using the household longitudinal data based on the India Human Development Survey in 2004-5 and 2011-12, we have applied the Propensity Score Matching to build a counterfactual group and have used the propensity-score weighted fixed effects model to eliminate time-invariant unobservable household characteristics. The results show that the IGNOAPS participation increased consumption expenditure, food and non-food expenditure and assets, while reducing the household labour supply. The sub-sample estimations show that these effects are observed only when recipients are women. However, the results of Difference-in-Difference model imply that the poverty-reducing effect deteriorated in 2011-12 after the government made several changes to programme specifications in 2007. This was likely because some households which accessed IGNOAPS after 2007 reduced the labour supply significantly while keeping the level of consumption.
\end{abstract}

Keywords: Pension, Ageing, IGNOAPS, Poverty, Household Welfare, India

\section{JEL codes: C23, I38, H75}

Acknowledgements: The authors would like to acknowledge valuable feedback from Kunal Sen, Raghav Gaiha, David Fielding, Subhasish Dey, and participants in internal seminar at the Global Development Institute, anti-poverty transfers research group seminar at the University of Manchester, 13th Annual Conference on Economic Growth and Development Economics and Planning Unit at Indian Statistical Institute, and the First Italian Workshop of Econometrics and Empirical Economics (IWEEE 2018): Panel Data Models and Applications. The authors appreciate valuable comments from two anonymous referees. However, the usual disclaimers apply.

*Corresponding Author: Vidhya Unnikrishnan, Global Development Institute, University of Manchester, Arthur Lewis Building, Oxford Road, Manchester M13 9PL, UK; Email:

vidhya.unnikrishnan@manchester.ac.uk 


\section{Does the old-age pension scheme improve household welfare? Evidence from India}

\section{Introduction}

As India's population has been ageing due to the decline in fertility and mortality rates, the focus of poverty alleviation programs has been gradually shifted to social assistance to the elderly which provides them with a safety net (Pal and Palacios, 2011). The data from the World Bank indicate that social assistance program accounts for 1.5\% of India's GDP in 2016, while in Brazil and South Africa, the government expenditure on social assistance programs accounts for $1.4 \%$ and $3.3 \%$ of GDP in $2015 .{ }^{1}$ The Employees' Provident Fund Organization and the Employees' State Insurance Corporation offer major social security plans and pensions to the workers in the formal sector (Uppal and Sarma, 2007). However, the formal pension schemes do not reach most of the informal workers which account for $92 \%$ of total employment in India (ILO, 2016). Also, the informal sector is usually associated with subsistence economic activities at low wages, which prevents workers in the informal sector - who are often poor from accumulating wealth over the life cycle. The lack of an institutionalised social security arrangement for the poor has highlighted the role played by Indira Gandhi National Old Age Pension Scheme (IGNOAPS) - a national social assistance program targeted on the elderly members of poor households in India. The primary objective of the present study is to evaluate the impact of the program on household welfare and poverty using the household longitudinal data based on the India Human Development Survey (IHDS) in 2004-5 and 2011-12. We propose to examine the impact of IGNOAPS on household welfare indicators capturing both direct and indirect effects, ranging from consumption expenditure, food and non-food expenditure (all on a monthly and per-capita basis) and household assets, to the number of persons working in the household and the household income excluding the IGNOAPS income. Our estimates on the programme impact on household consumption, the labour market participation and household income would shed some light on the mechanism whereby a 
recipient household reduced poverty. The secondary objective of this study is to examine whether these effects improved or weakened, after the government made a few change to the programme specification in 2007 , such as the eligibility criteria.

Research shows that two-thirds of the elderly in India live in villages, nearly half of whom are poor (Lena et al., 2009). The census in 1991 shows that about half of the elderly females were either widowed, divorced, or separated, and they were likely to be vulnerable (Rajan, 2001). There has also been an increase in the economic compulsion to work for the elderly in India (Singh and Das, 2015). Although the option of continuing to work helps the elderly to lead an active life, the elderly engage in the informal sector and earn lower pay than workers in their prime age in developing countries (Kidd and Whitehouse, 2009).The rapid ageing population growth in India ${ }^{2}$ makes it essential to understand the impact of existing policy levers, as these policies are likely to be expanded in the future with the increase in the elderly population.

There are three major contributions the present study aims to make. First, on the technical side, we use a longitudinal dataset based on IHDS in 2004-5 and 2011-12 and apply the household fixed effects (FE) model to it to estimate the impact of IGNOAPS on household welfare indicators. In this model, participating and non-participating households are matched by Propensity Score Matching (PSM) so that they are comparable with each other. Furthermore, the regression is weighted by Propensity Score (PS) to take account of the probability of participating in the household to reflect its differential incentive to join the scheme. While the previous study on IGNOAPS has only used cross-section data (Garroway, 2013; Kaushal, 2014), our study provides more robust estimates based on the improved methodology and data. Second, we estimate the impact of IGNOAPS on a wide range of household outcome variables, such as household consumption, income, assets and household labour supply to identify how households behaved differently depending on whether they participated in the programme. The 
results of various sub-sample estimations compare the programme effects by gender, household's political connection and caste group. Third, we have examined whether the change in the programme specification in 2007, such as the change in the eligibility criteria, strengthened or weakened the welfare effects based on the Difference-in-Difference (DID) model applied to the panel data. This is, to our knowledge, the first study to examine whether and how IGNOAPS reduced household poverty drawing upon the panel data based on the nationally-representative household survey in the Indian context.

The rest of the paper is organised as follows. The next section will review the relevant literature. We will explain our data and empirical strategies in detail in Section 3 while presenting and discussing the econometric results in Section 4. Concluding observations will be offered in Section 5 .

\section{Literature review}

Social assistance programs in the form of cash transfers have become one of the most common policy options for poverty alleviation in developing countries given the widely known success of conditional cash transfer programs in Latin America, notably in Mexico and Brazil since the late 1990s, and their replications in other developing countries, including India (Randive et al., 2013). Cash transfer programs can be both conditional and unconditional. Conditional cash transfers provide payments as long as beneficiaries commit to attaining the program objectives; unconditional cash transfer offers cash transfers without any conditions attached to transfer. It will work if the recipients are aware of the choices that need to be made with the money (Narayanan, 2011). The advantage is that it involves fewer compliance issues.

IGNOAPS is as an unconditional cash transfer program targeted to the elderly. Due to the non-restrictive nature of the program, unconditional cash transfers can potentially result in changes in various outcome variables. The impact of South Africa's old-age pension scheme is 
a widely touted example of unconditional cash transfer. Case and Deaton (1998) studied the re-distributive effects of South Africa's old-age pension and found that both pension and nonpension income had the same positive effect on food expenditures. The arrival of social pension can also change the living arrangements of the recipient households. Old age pension received by an elderly grandmother in South Africa promotes interdependence, as grandmothers act as caretakers for grandchildren, encouraging labour market mobility of younger mothers (Edmonds et al., 2005). Duflo (2003) confirmed a positive effect of old-age pension on the health outcomes of girls in the household.

On the impact of UCTs on labour supply Abel (2019) found that pension reduced the household labour supply as it increases household income and pushes up reservation wages. Posel et al. (2006) showed that pension income for old women enables working-age women to migrate and work away from the household. Haushofer and Shapiro (2016) found that in Kenya cash transfers provided every month improved household food security, while a lump-sum payment increased household expenditure and enhanced the beneficiaries' psychological wellbeing. On evaluating the impact of South African Old Age Pension, Case and Menendez (2007) confirmed that the presence of a pensioner reduces household food insecurity among adults and children and co-residing with a female pensioner encouraged enrolment of girls in school. The theory of change illustrated by Bastagli et al. (2016) highlights various responses generated by the cash transfer program. The most immediate response of recipients to a cash transfer programme is to increase their general household consumption expenditure, food expenditure, and spending on other necessities. The arrival of additional non-labour income also may ease credit constraints and help forming household assets. Cash transfer programs increase household consumption, which can shorten the time spent on work (the income effect), thereby reducing the household labour supply. Drawing upon the literature on evaluations of social 
protection policies and the theory of change reviewed above, we have selected various outcome variables to estimate both direct and indirect effects of IGNOAPS.

There have been few studies in the literature that have evaluated the impact of the pension programme in the Indian context despite its scale and significance in governmental policies to support poor households with elderly members. An exception is Kaushal's (2014) work that estimated the effects of IGNOAPS on the elderly well-being, living arrangements, employment, and expenditure pattern based on the National Sample Survey (NSS) data, but the author used only a proxy measure on education to identify program recipients because NSS did not collect any data on IGNOAPS recipients. To overcome this drawback, we have used the IHDS panel dataset which has precise details on program beneficiaries. We can thus identify the treatment status regarding IGNOAPS participation far more accurately than Kaushal (2014) who used only a proxy measure. Furthermore, we will use a PS weighted FE model for the panel data where PSM matches beneficiaries and non-beneficiaries to remove any bias due to sample selection and the effects of time-invariant unobservable characteristics. This methodology takes account of different eligibility criteria before and after 2007 and across different states. This is a significant development from Kaushal (2014) based on the cross-sectional data.

\section{Indira Gandhi National Old Age Pension Program}

The Central Government of India introduced the National Old Age Pension Scheme in 1995. The program eligibility criteria used in the initial phase was that the beneficiary has to be 65 years of age or older, and a destitute with no regular source of income or support from family. The central government provided 75 Indian National Rupees (INR) to eligible beneficiaries. In 2003, National Old Age Pension was transferred into State plan. This offered the State Government the flexibility with the implementation process, but the Central Government continued assisting the programme. In 2007, the scheme was renamed and relaunched as Indira 
Gandhi National Old Age Pension Scheme (IGNOAPS). ${ }^{3}$ The eligibility criterion changed with someone being destitute to belonging to a Below Poverty Line, also known as BPL household. The Central Government also increased the benefits from INR 75 to INR 200. The second round of change happened in 2011 when the Central Government reduced the age eligibility threshold for the program from 65 years of age to 60 years. ${ }^{4}$

Overall, the program underwent several rounds of iterations, which include a reduction in the age threshold for the program participants, an increase in the transfer amount, and the program covered Below Poverty Line households. State Government in India has reacted to these changes differently. Kaushal (2014) has provided a rich discussion on the varied response which the State Governments provided regarding the reduction in age threshold and the increase in transfer amount. The author highlighted that in 2007, 12 States did not make any contribution in addition to the Central Government's assistance, and there are uneven contributions made by other States towards IGNOAPS. Even when the pension eligibility age for the program was 65 years, there were variations in eligibility age followed the States; with some States using the threshold of 60 years and some following 65 years for male and 60 years for female. Rajasthan adopted the lowest age eligibility criterion. The targeted beneficiaries in the state include males who were 58 years old and females who are 55 years old. The unevenness in the State contribution towards IGNOAPS persisted even in 2011when some States did not assist, and some States topped up four times more than the Central Government's input (see Appendix 1). From the IHDS data, we infer that the average annual transfer amount received from IGNOAPS was INR 1818 in 2004-5, and this increased to INR 4105 in 201112. The IHDS data show that between the two rounds, the total number of recipients in the program grew from 1520 to 4477 and the number of poor recipients from 915 to 1723.

With the increase in the elderly population in India, there has been a rapid expansion of this programme. In 2002-03 IGNOAPS covered 6.7 million beneficiaries, and by 2012-13, the 
number of beneficiaries covered under the scheme has more than tripled to 22 million. ${ }^{5}$ The expenditure allocation on IGNOAPS has increased by 1.4 times between 2007-08 (INR 29 billion) and 2011-12 (INR 42 billion). $^{6}$

\section{Empirical framework}

\section{Data}

We have used the panel data based on IHDS, which collected the information at both household and individual levels. The survey has covered a wide range of topics that include social capital, labour, education, health, and expenditure incurred. IHDS currently consists of two rounds. IHDS-1 is a nationally representative survey conducted in 2004-5. IHDS-2 was conducted in 2011-12 to re-interview 40,018 households (including split households) and add further 2,134 households. For our research, we have used the panel dataset at the household level. The household panel data have 40,018 households interviewed in both periods (Desai, Vanneman and National Council of Applied Economic Research, 2005 and 2012). Appendix 2 reports definition of the variables used in this research.

Table 1 shows descriptive statistics of the variables that we use in our regression analyses. This provides a contrast between beneficiaries and non-beneficiaries at household levels over outcome variables, (ii) explanatory variables used for probit models (for PSM) and (iii) those for FE or DID models. Table 1 is based on the data matched by PSM and weighted by the estimated PS. The second panel of Table 1 shows that beneficiaries and non-beneficiaries are reasonably balanced in the explanatory variables for probit models as the means of most of the explanatory variables are similar, although there are a few variables (e.g. Antyodaya card) where t-test rejects the null hypothesis of equality due to the large sample size. The average annual amount of IGNOAPS increased from INR 2242 to INR $2548 .^{7}$ Most of the outcome variables (e.g. MPCE (food), assets and household income excluding the IGNOAPS payment 
in the first round) on average higher for beneficiaries than for non-beneficiaries. In the next section we will examine more formally whether the programme actually improved the outcome variables.

\section{[Table 1 to be inserted around here]}

\section{Empirical Strategies}

There are three empirical challenges that we face, as we estimate the effects of IGNOAPS on household welfare. The first challenge is that, unlike an experimental framework, such as Randomised Control Trials, we lack a valid counterfactual group. As a household can selfselect itself into IGNOAPS, the estimates on the effect of the programme may be biased without addressing the sample self-selection bias. The second constraint is to eliminate time-invariant unobservable characteristics in our model. The third challenge arises from the change of the programme specification, in particular the eligibility criteria, between 2004-5 and 2011-12. An incentive to participate in the programme changed between the two rounds in response to the specification change. We will estimate the household-level incentive to participate in the programme to take into account any change in incentives for participation that was caused by changes in the programme specification.

We will address these three challenges by two-step procedures. First, we will estimate the PS, or the probability of a household participating in the programme, by the probit model applied to each round of the panel. PS reflects differential incentives of the household participating in the programme not only across households but also over time. Hence, this will address the third challenge, that is, the change in the specification of the programme in the panel setting. We use the PS to match the beneficiary households and non-beneficiary households to make them comparable. The PSM method eliminates households which are not comparable with each other. For instance, if non-beneficiaries include wealthy households with little incentive to participate in IGNOAPS, the impact of the programme of improving welfare 
might be underestimated. The use of a matched panel in all our estimations ensures robust estimates.

In the second step, we will apply the fixed-effect (FE) model to take account of the unobservable factors at household levels, which are assumed to be unchanged over time (the second challenge). Here we weight the regression based on a PS. Using a PS as a weight will not only minimise a potential bias in our estimates of the effect of IGNOAPS on outcome variables that may arise from the sample selection into the programme (the first challenge) but also take into account any changes in household incentives to participate in the scheme due to the programme specification change in 2007 (the third challenge). The method of matching and employing the FE model answers the question on the impact of a household gaining access to the program in any one of the rounds on the consumption outcomes, labour supply decisions and assets held. As the PS reflects how likely each household would participates in the programme given the household characteristics, including age profiles, our methodology will also address differential incentives in response to different eligibility criteria across states.

As an extension, to estimate the impact of the program specification changes which took place in 2007, we will use the DID method in the matched data. The DID model is used to estimate the impact of the policy changes that took place in 2007 and compares the outcome variables between the program recipients and non-recipients. In subsequent paragraphs, we will discuss the methodologies outlined above in more details.

\section{First Step: PSM}

The PSM method (first proposed by Rosenbaum and Rubin, 1984) matches the treated group of households with the control group based on observable characteristics. We match units of observations (households) based on their propensity to participate in IGNOAPS. We carried out matching based on the binary variable on participation status rather than the amount of 
social pension that participants received to avoid complication. For the first round, we used the entire sample of households, including those which dropped out in 2011-12, in order to address the attrition problem. We construct a PS based on the covariates that determine participation in the program, and also simultaneously affect outcomes (Caliendo and Kopeinig, 2008). The covariates in the probit model includes 'BPL card', 'Antyodaya card', 'the presence of an elderly member in the household if the household lives in a rural area' and 'attends public meetings', 'highest education in the household' and 'if the household belongs to a scheduled caste or a scheduled tribe'.

There were two changes the central government made in the eligibility criteria between the two rounds. The first is that the eligibility criterion changed from someone being destitute to belonging to a BPL household. However, there was actually no formal identification mechanism used to identify a destitute and so we cannot use the criterion on destitute in the 2004-5 analysis. The age eligibility criterion also changed in 2011 as the central government lowered the age threshold from 65 years to 60 years. Despite a few changes in the eligibility criteria between the two waves, we use broadly same variables in estimating the probit model. ${ }^{8}$ The result from the first stage probit model in Appendix 3 shows that a household having a BPL card has a higher probability of receiving the treatment. It is noted that the BPL card holding is determined by 13 parameters, one of which is the operational landholding in 2002 . As such, the BPL card holding status captures a poverty status in multi-dimensions, including asset status of a household, which would justify our use of current household asset index as one of the outcome variables. Similarly, households having an Antyodaya card also have a higher probability of receiving treatment. A household with an elderly member has a higher probability of receiving the treatment, and if the household head belongs to a socially disadvantaged caste, then the probability of receiving it increases. Residing in the rural area 
and attending public meeting increases the probability of receiving IGNOAPS. The variable reflects upon the awareness of the scheme, which increases the likelihood to receive IGNOAPS. However, higher years of education reduce the probability of receiving IGNOAPS. Education is a predictor for better-earning outcomes, and this reduces the dependence on the welfare program.

We then use kernel matching where we apply weighted averages of all households in the control group to build the counterfactual group to pair treatment with control units. We have performed a test to ensure that the covariates used in the construction of PS are balanced in both treated and control groups such that these groups are comparable. ${ }^{9}$ The graphs on common support regions (Figures 1 and 2) and the distribution of the propensity score (Figures 3 and 4) in the treatment and matched control group are shown below. As shown in Figures 1 and 2, the observations outside the region of common support (those with the propensity score above 0.2 in 2004-5 and above 0.45 in 2011-12) have been dropped as no comparable control households exist. Figures 3 and 4 show that the treatment and control units have a similar distribution in the area with the propensity score above 0.05 .

\section{[Figures 1, 2, 3 and 4 to be inserted around here]}

We repeated the same procedure separately for the two rounds and dropped the households outside the region of common support (1,698 households in the first round and 11 in the second round). After dropping them, we have 38,320 households in 2004-5 and 40,007 households in 2011-12 rounds. As a result, we lost $4.24 \%$ of households in the $2004-5$ rounds, and $0.03 \%$ of the households in 2011-12. We then constructed a balanced panel dataset with households that are present in the common support in both rounds of the survey. The balanced panel dataset consists of 38,309 households.

\section{Second Step: FE model with PS weighting}


Angrist and Pischke (2008) suggest that if the panel data are used for impact evaluations the effects of confounding unobservable time-invariant characteristics on the outcome variable and program participation can be eliminated by using FE regression estimation technique. The advantage of using a FE regression method is that it wipes out the effect of time-invariant unobservable household characteristics that would affect outcome variables. Therefore, we estimate the effect of treatment on the outcome variables using a FE model.

Even if the exogeneity condition is satisfied for the IGNOAPS participation, a bias in the estimate may remain if participants and non-participants are not comparable where, for instance, rich households without any incentive to participate in the scheme are included in the control group. To address this limitation, we have combined the FE model with the matching method to ensure that treatment and control groups are comparable. ${ }^{10}$ Furthermore, we put differential weights for the treatment and the control using the PS. The methodological framework of combining PSM with fixed effects was also used by Imai and Azam (2012) to study the impact of microfinance on poverty in Bangladesh. The method of matching with FE is also used by Kim et al. (2008) to understand the effects of precarious employment on selfreported health in South Korea.

\section{The FE Model with PSM and with PS weighting ${ }^{11}$}

The fixed effects equation that we estimate is:

$$
Y_{h t}=\beta_{0}+\beta_{1} \text { IGNOAPS recipient }_{h t}+X_{h t} \beta_{2}+\mu_{h}+e_{h t}
$$

The outcome variables $\left(Y_{h t}\right)$ estimated here is log monthly real per capita expenditure (MPCE) at the household levels for the $h^{\text {th }}$ household in round $t$ (2004-5 and 2011-12). Alternatively, we have also used for a dependent variable, $Y_{h t}$, log monthly real per capita food expenditure (MPCE (food)), log monthly real per capita non-food expenditure (MPCE (non-food)), the log 
of the asset index, log number of household members working or log household income excluding IGNOAPS. We also use poverty based on per capita household expenditure as $Y_{h t} \cdot{ }^{12}$ We are primarily interested in the parameter estimate $\beta_{1}$, for the variable IGNOAPS recipient $_{h t}$ (a binary variable that takes the value one if the household receives any money from IGNOAPS and zero otherwise). As we have noted, while the eligibility criteria changed between the two rounds, the estimation will be weighted by the PS, which reflects a differential incentive into the programme across households over the years. ${ }^{13}$ Explanatory variables in the probit model in the first step include the eligibility criteria for the programme and, despite the limitations ${ }^{14}$, our methodology would be one of the few to address the third challenge, that is, the change in the programme specification in 2007 . Here $\hat{\beta}_{1}$ indicates the average effect of receiving IGNOAPS on each outcome variable.

It is noted that IHDS has constructed monthly per capita expenditure using a broad set of variables that reflect the purchasing power of the household. The food and non-food categories of spending represent only a subset of the total monthly per capita expenditure. On average, the basket of food items included in the food expenditure represents $41 \%$ of the total spending in $2004-5$ and $39.6 \%$ of the share in total expenditure in 2011-12. The list of non-food items included in the analysis on average constitutes $23.3 \%$ of the aggregate expenditure in 2004-5 and $25.8 \%$ in 2011-12. We have controlled for the effects of other time-varying covariates $\left(X_{h t}\right)$ in the regression model. $\mu_{h}$ represents the time-invariant unobserved household heterogeneities. $e_{h t}$ is the error term at the household level. Although IGNOAPS is provided at the individual level, the outcome variable we use is defined at the household level mainly because the survey data do not have information on assets held, consumption, food, non-food expenditure incurred at individual levels. We also implicitly assume the unitary household model in defining poverty drawing upon a large body of empirical literature on poverty studies in developing countries where a household is assumed to have a common set of preferences 
while recognizing the importance of taking into account the individual welfare in defining poverty (Alderman et al., 1995). The unit of analysis is key to specifying the fixed effects imposed, and this is the reason that we used household fixed effects.

A vector of the control variables $\left(X_{h t}\right)$ include the number of children, the number of elderly male, the number of elderly female, household compositions or the size excluding children and elderly members, the highest level of education in the household, place of residence, women's access to mass media, the household head is a Hindu, caste, and other welfare programs received by the household. In selecting these control variables, we have followed the empirical literature on the impact evaluations based on non-experimental household data we have reviewed in Section 2 (e.g. Pal and Palacios, 2011) while adjusting the specification given the data availability and the study context. The regression is weighted by the estimated propensity score following Hirano and Imbens (2001), Hirano et al. (2003), and Michalopoulos et al. (2004). Under the unconfoundedness assumption for PSM that the treatment is independent of outcome conditional on pre-treatment variables, we assign the sample weight of 1 for all the households in the treatment group and $\mathrm{p} /(1-\mathrm{p})$ in which $\mathrm{p}$ is the estimated Propensity Score (PS) for households in the control group to derive the (conditional) average treatment effect on treated(ATT) (Hirano and Imbens, 2001). The PS weighted FE model applied to the matched panel is designed to minimize sample selection bias arising from the differential propensity to participate in IGNOAPS in the panel data setting (Linden and Adams, 2010). As we have noted earlier, our model will take into account the fact that the programme specification or the eligibility criteria changed between 2004-5 and 2011-12. This is because in our model nonparticipating households in each round are assigned the weight, or the probability of being included in the regression, reflecting how likely they could have participated in the programme which is a function of the eligibility criteria in each round. This is, in our view, one of the methodologies which can provide robust estimates of the programme impact given the data 
constraints where (i) there was no baseline without interventions and (ii) the eligibility criteria changed over time. ${ }^{15}$

\section{An extension: the DID model to evaluate the effect of changes of the programme in 2007}

In light of the major changes of the programme specification in 2007, we examine whether the households which received the programme in 2011-2012 had a better welfare outcome than non-beneficiaries. We apply a version of the DID model to identify the effect of programme specification changes in 2007. Here the PS-weighted FE model is used for the matched panel only for a sub-set of the panel in which households did not participate in the programme in 2004-5. This model identifies the effect of the change in participation status by comparing the sample households which remained non-participants and those which started to participate only after 2007. Unlike the standard DID settings, we do not have baseline data without any participants as there were already both participating and non-participating households in 20045. To reduce any sample selection bias as well as attrition bias, we have weighted in the regression by PS so that the regression reflects the probability of the household participating in the programme in 2004-5 and 2011-12 as different households had different probabilities of participation. So, while this is not a perfect solution to eliminate sample selection bias completely as PS is subject to the specification and the results of the probit model, the PSweighted DID model would provide a robust estimate given the data constraints. ${ }^{16}$ We estimate the following model:

$Y_{h t}=\alpha_{0}+\alpha_{1}$ Post $2007+\alpha_{2}$ new IGNOAPS recipient $+\alpha_{3} X_{h t}+\mu_{h}+e_{h t}$

where $Y_{h t}$ denotes the outcomes variable, Post 2007is a dummy variable for the year 20112012, and new IGNOAPS recipient stands for a dummy variable on whether a household participated in IGNOAPS in 2011-12, not 2004-5. This variable identifies the effect of new participation on $Y_{h t}$ in comparison with the households which remain non-participants and are 
comparable with new participants in terms of the probability of participating in IGNOAPS. ${ }^{17}$ $\widehat{\alpha}_{2}$ thus provides a DID estimate indicating the effect of the programme change on outcome variables and $\widehat{\alpha}_{2}$ is shown to be consistent in a two-wave panel data model with unit and time fixed effect (Heckman and Robb, 1985; Galiani et al., 2005). $X_{\mathrm{ht}}$ denotes a vector of control variables. $\mu_{h}$ is the household level fixed effects.

\section{Econometric Results}

In this section, we will present and discuss the main econometric results based on Equations (1)-(2) in the last section. We will focus mainly on key findings on whether and why IGNOAPS reduced or did not reduce, household consumption based on the results on various outcome variables.

\section{The Results of the FE Model}

Table 2 reports the results of the FE model (Equation (1)) based on the PS weighted FE model applied to the matched panel data. As the first row of Table 2 indicates, a dummy variable on whether a household receives IGNOAPS shows an expected sign with significant parameter estimates in all the cases except the last two columns, poverty and income excluding the IGNOAPS payment. The results support our hypothesis that participation in IGNOAPS improved household welfare over time. Table 2 has confirmed that IGNOAPS participation significantly increased household consumption expenditure through food expenditure and selected items on non-food spending. Increase in food expenditure as a result of cash transfers is consistent with Haushofer and Shapiro's (2016) results in Kenya. Non-food expenditure only covers spending in non-luxuries, necessities and services (e.g. toiletries, transportation, services on domestic servants, or out-patient medical expenses) and excludes luxuries or unusual spending. The parameter estimate on non-food expenditure is larger than that of food 
expenditure or total expenditure (including luxuries or unusual spending, defined by IHDS), implying that the programme participation enabled households to spend on necessary items and services, which would improve the household welfare significantly. In terms of the magnitude, households receiving IGNOAPS increased their consumption expenditure by $5.5 \%$ on average evaluated at the mean (from INR 864 to INR 912). Likewise, beneficiaries of IGNOAPS augment their food expenditure by 5.8\% (from INR 366 to INR 387) and increased non-food expenditure (on necessities) by $8.7 \%$ (from INR. 231 to INR. 252). We have also found that access to the program is likely to lead to a larger level of the household asset (e.g. sewing machine, radio, TV, refrigerator) by $10 \%$, implying that some households increased on spending in assets.

As expected, the number of household members working in the labour market reduced as a result of IGNOAPS participation. We find that the program significantly reduced the labour supply by $10 \%$ (from 2.15 members to 1.93 ). There is no significant effect on poverty. This could be because a significant number of non-poor people participated in the scheme as we will discuss later or consumption increase by $5.5 \%$ was not large enough for poor households to cross the poverty threshold. We find that the income excluding IGNOAPS reduced by $1.2 \%$ though it is not statistically significant. Overall, IGNOAPS was found to be welfare improving as it relaxes the budget constraint and enables households to spend more on food, necessities, and assets without reducing the household income other than IGNOAPS significantly.

\section{[Table 2 to be inserted around here]}

IGNOAPS income for the elderly member increased the demand of goods and services for the entire household (income effect), and this is reflected in higher per capita expenditure, food, non-food expenditure and improvement in assets. Given that consumption is a broad indicator of household wellbeing, an increase in consumption indicates the ability of the program to reduce household poverty, although the effect on 'poverty' is not statistically significant. 
Because the program is targeted at the poor, a priori expectation is that the program will have a substantial effect on food expenditure. However, we observe that there is a substantial impact of the program on non-food spending and household assets. With the increase in non-labour income, a household became able to spend more on non-food expenditure, mainly on necessary items and services. The category of non-food spending also includes outpatient medical services. Households that receive IGNOAPS on average spend INR 112.6 (monthly/per capita) for outpatient medical services, which constitute the largest component of expenditure incurred in the non-food category. UCT allows beneficiaries to decide on how to utilise funds. The treatment group's choice of investment in assets reflects the long-term poverty reduction strategy of households (Angelucci et al., 2012).

On further disaggregating the data, we find that households had a higher allocation of the payment of IGNOAPS towards non-food spending and household assets. Outpatient medical payments mainly drive substantial spending on non-food expenditure. Although India has made medical strides over the years in the reduction of mortality rates and the improvement in life expectancy, there exists a vast rural-urban divide in the quality of medical services provided. Also, the poor in India do not have easy access to the health insurance market, which further increases their expenditure on the outpatient facility (WHO, 2010). Households also use IGNOAPS for asset creation.

Social insurance and social assistance programs can affect the household labour supply through income and substitution effects. An income effect does not create a deadweight loss, but instead, it is the intended outcome of the program. A substitution effect creates a deadweight loss in the economy. The income effect is observed if, with the arrival of IGNOAPS, households decide to reduce the number of hours spent on work or withdraw from the labour market. Unearned income can relax liquidity constraints or smooth household consumption thereby helping households to reduce their labour supply (income effect) (Ning et al., 2016). 
As Ning et al. show, the substitution effect occurs only if implicit taxes are imposed on workers who continue to work after accessing the pension programme. In that case, the substitution effect will create a deadweight loss in the economy as in the case of some contributory pension system or social earnings test that discourages working. A deadweight loss is created here because people work less and the economy's output shrinks because of the implicit tax imposed on workers who work after the arrival of pension. The purpose behind the implicit tax for the government is to increase revenue, but this becomes counterproductive as it discourages individuals from working and reduces government tax revenue. However, we overrule any substitution effects here as the program does not impose any labour inactivity condition. The age eligibility criterion followed in IGNOAPS coincides with the retirement age, so the beneficiaries are not expected to contribute to the labour market, and so it is surmised that the elderly members reduced their labour supply. Therefore, we can conclude that IGNOAPS reduced the household labour supply through its income effect. Appendix 4 reports a full set of results where the control variables included in the models display the expected sign. ${ }^{18}$

IHDS-2 has details on whether households have Rashtriya Swasthya BimaYojana (RSBY - 'a national health insurance programme' for the poor) card. A little more than $25 \%$ of IGNOAPS recipient households have RSBY card in 2011-12. Since we have information on RSBY only for 2011-12 in our dataset, we have estimated the results for non-food expenses for the 2011-12 rounds. After controlling for the effects of RSBY, we find a household's access to IGNOAPS reduces the non-food expenses in 2011-12 rounds. This finding corresponds to our earlier results that the medical expenditure drives substantial spending on non-food payment. To further understand the effects of health insurance, we have also estimated the effects of having both IGNOAPS and RSBY on the non-food expenses. The interacted variable is useful to answer if households having to access to both old-age pension and health insurance 
still incur a substantial allocation on non-food expenses. We do not find any statistically significant effect of the interacted term on the non-food expenses.

\section{Extensions}

In Table 3, we have carried out a few extensions using the PS-weighted FE model for the matched panel. First, we have replaced a dependent variable by a binary variable on whether elderly members are working in a household. Our results on the effect of IGNOAPS on elderly labour supply suggest that program participation reduces the probability of elderly members working by $12.7 \%$.This result indicates that IGNOAPS reduces elderly member's economic need to work. Second, we have also analysed the impact on the outcome variables if the pension recipient is a male/female by replacing a dependent variable by a binary variable on whether male members (or female members) are IGNOAPS recipients. We find that MPCE and food expenditure increased only when recipients are female. The increase in assets formation is slightly larger when the recipient is female compared to being male.

\section{[Table 3 to be inserted around here]}

The difference in the behavioural responses to cash transfer between male and female recipients suggests that households are non-unitary. The standard unitary model assumes that a household maximises a single utility set, and cash transfer to men and women will generate similar welfare effect as they both have a common set of preferences. This has been increasingly challenged by many studies, as research suggests that individual preferences influence household allocations. Income transfers focused on women encourages expenditure on children, nutritious specific goods (Bobonis, 2009; Duflo, 2003) as women tend to allocate higher shares of spending on health and nutrients than men (Thomas, 1990). The positive effect of the food expenditure variable when the program recipients are females further substantiates the results from the literature. 
The findings from the sub-sample estimations (male/female) suggest that participation in IGNOAPS does not affect non-food expenditure contrary to the result in Table 2 . When women participate in the programme, the household significantly increases total consumption expenditure by $5.9 \%$, food expenditure by $7.3 \%$, assets by $7.4 \%$, and reduced the labour supply by $3.2 \%$. Non-pension income increased by $4.9 \%$, but the parameter estimate on non-pension income and labour supply is not statistically significant. ${ }^{19}$ On the contrary, the household does not respond to IGNOAPS when men receive the payment with much smaller and statistically insignificant parameter estimates in all the cases, except improvement in household assets $(5.1 \%)$. We can conclude that the household welfare improvement of the IGNOAPS is realized when women participate in it. Importantly, our result suggests that women used the IGNOAPS payment for the household food expenditure, which is likely to lead to better food security and nutritional conditions of household members. Thirdly, the sub-sample estimations for households with political connection indicate that welfare-improving effects are not observed for these households, implying that there is no role of political connections in enhancing the programme impact. Finally, our analysis on the sub-sample of households whose household head belonged to the scheduled caste or scheduled tribe suggests that IGNOAPS is a significant determinant of assets held (10.7\%), and household labour supply (-8.9\%). Given that a household that is socially marginalised also tends to be economically marginalised, our results implied that the programme increased assets formation among socially marginalized households. The last column shows that there is no statistically significant effect on poverty and household income.

\section{DID estimates of changes in the programme specifications in 2007}


Finally, Table 4 reports the results of the DID model that analyses the effect of the programme specification changes in 2007 on outcome variables. These are based on the PS-weighted FE model applied to the matched panel to mitigate sample selection bias.

\section{[Table 4 to be inserted around here]}

Here we use the matched panel only for the households which did not receive IGNOAPS in 2004-5. We have found that new IGNOAPS participants after 2007 did not increase total expenditure, food or non-food expenditure, or poverty, but they significantly increased assets by $4.7 \%$ on average evaluated at the mean and reduced household labour supply by $4.8 \%$ and also significantly reduced the household income (excluding IGNOAPS payment) by $12.9 \%$. Asset increase is nevertheless realised through the income effect because, once the IGNOAPS payment is included in the household income, 'new IGNOAPS participants' increase it significantly by $23.8 \%$. The results imply that the programme impact deteriorated as beneficiary households further reduced the labour supply after 2007 in response to the change of the age threshold from 65 to 60 years, leading to a significant reduction in non-pension household income. However, the new recipient households tend to spend the income from IGNOAPS on household assets. It is surmised that after 2007 some recipients stopped working and invested in household assets, while keeping the level of consumption.

The DID results suggest that the expansion of the program in 2007 did not lead to a significant welfare improvement in terms of consumption expenditure, but increased assets significantly. This could be associated with the change in the program specifications, which would increase the cost of participation or administrative burden for the poor (e.g. more paperwork). This is reflected in the increase in exclusion targeting error (Type 2 error) in the program, where poor eligible people did not participate ('undercoverage'). The exclusion targeting error in the program has increased from $47.5 \%$ in $2004-5$ to $74.2 \%$ in $2011-12$. In the meantime, the extent to which non-poor ineligible people accessed the programme ('leakages' 
or Type 1 error) improved from $60.2 \%$ in $2004-2005$ to $38.5 \%$ in $2011-12$, but it remained at high levels in the second round. Asri (2019) discusses the widespread exclusion targeting error prevalent in the program.

Non-poor recipient households may have fewer incentives to increase food or non-food consumption, but more incentives to increase assets. ${ }^{20}$ Although the program expansion has increased the cost of participation, for those households that gained access to the program, the pension payments were large enough to reduce their household labour supply. The reduction in household income excluding the payment from IGNOAPS further corroborates that the new program recipient households have reduced their efforts in the labour market. ${ }^{21}$

While we examined the overall effect of IGNOAPS in Table 2, we focused only on the effect on the new participants in the second round to analyse the effect of the specification change of IGNOAPS in Table 4, and the results can be different. However, given that the new participants are a subset of the entire participants in the programme, it is evident that the welfare-improving effect of the programme deteriorated significantly after the programme specification change in $2007 .{ }^{22}$ Given the size of average reduction of non-pension income in 2011-12 (13.4\%, INR 6611), which is much larger than the average IGNOAPS payment in 2011-12 (INR 2548), there was likely to be a disincentive effect of the programme where some beneficiary households became dependent too much on the programme after 2007 . Why this occurred only after 2007 is a puzzle. This may be due to the psychological effect or the difference in behavioural response of poor and non-poor households. This is beyond the scope of the present study; future research can investigate this.

\section{Conclusion}

This study has evaluated the effects of IGNOAPS on a range of welfare indicators, such as household consumption, assets, non-pension income and poverty, by using the panel data on 
India based on the IHDS survey in 2004-5 and 2011-12. Given that households self-select themselves in participating the programme and the programme specification, such as the eligibility criteria, changed in 2007, we have first applied the FE model for the panel data where participating and non-participating households matched by PSM to take account of differential incentives for participating in the programme across different households and over time. This identifies the overall effect of programme participation. We have then applied a DID model for a subset of the matched model (for the households which did not participate in 2004-5) and have weighted by the PS to identify the effect of IGNOAPS on household welfare for those who chose to participate after the specification of the programme in 2007.

The results of FE with PSM and PS weighting show that IGNOAPS increased household welfare outcomes in terms of total consumption by $5.5 \%$ on average, food consumption by $5.8 \%$, non-food consumption on necessities by $8.7 \%$, household assets by $10.0 \%$, while it reduced the household labour supply by $10 \%$ and had no effect on poverty and non-pension household income. With the arrival of an additional source of non-labour income through IGNOAPS for the elderly member, there is an increase in demand of goods services for the entire household (income effect), and this is reflected through higher per capita expenditure, food, non-food expenditure and improvement in assets. Presumably, while the participant members work less in the labour market, non-pension income is kept. These results confirm the welfare-improving effect of the programme. We have also analysed the impact on the outcome variables if the pension recipient is a male or a female and have found that consumption expenditure, food expenditure increased only when recipients are female. The increment in assets formation is more substantial in households with female recipients than those with male recipients. This suggests different behavioral responses between men and women (e.g. women tend to use the pension income for the household food expenditure), which 
have been found in the previous works (Thomas, 1990; Duflo, 2003, Bobonis, 2009) and does not support the unitary household model.

However, the welfare-improving effect deteriorated after 2007 as suggested by the DID results with PSM, and PS weighting applied to a sub-set of beneficiary households, that is, those who started to participate after 2007 ("new IGNOAPS participants") and the matched non-beneficiary households. While consumption expenditure remained unchanged regardless of its definitions (i.e., total, food, or non-food), household assets increased by $4.7 \%$ and the labour supply reduced by $4.8 \%$. Notably, non-pension income reduced by $12.9 \%$ due to the participation. This is partly because the targeting performance of the programme worsened in 2011-12 where a significant share of non-poor households participated in the programme despite the changes of eligibility criteria between the two rounds where the poverty criterion changed from "being destitute" to "belonging to a BPL household" and the age threshold changed from 65 years to 60 years. That is, new participants in IGNOAPS that consist of a significant number of the non-poor did not use the programme as a means of escaping from poverty, stopped working and invested in household assets, while not changing consumption expenditure significantly. As Asri (2019) shows, BPL card as eligibility criterion was misused by non-poor individuals and poor older people lacking a BPL card did not access the programme. This caused some disincentive effects among the beneficiary households, where they reduced the labour supply and non-pension income. Our results are consistent with the existing evidence that household income may not always increase corresponding to the transfer amount, especially if the program reduces other possible income components (Attanasio and Mesnard, 2006). The negative effect of IGNOAPS on the household labour supply implies that other sources of income are reduced, which explains why we do not find any overall impact of the programme on poverty or income. It is noted that the poverty reducing effect of the cash 
transfer program is conditional on the extent to which it affects work incentives (Skoufias and Di Maro, 2008).

The challenge for policymakers is to improve the targeting performance of IGNOAPS to reduce poverty under the severe budgetary constraints faced by central and state governments. Ideally, the amount of programme payment should be increased given the relatively small effect of additional pension income on poverty, but this would further worsen the targeting performance. The priority is for each state to review the eligibility criteria so that more poor households access IGNOAPS to escape from poverty.

Although the findings from the paper provide key policy insights about the program, there are some limitations here. First, the income effect is the possible mechanism through which the findings in this paper are explained. This is justified as the program participation increases the purchasing power of the recipients (monthly per capita expenditure) and the demand for goods and services (food, non-food expenditure). However, to further corroborate this finding additional evidence needs to be provided by disaggregating the food expenditure, and examining if pension recipient households are shifting from cheaper to expensive food items. Second, we have provided evidence on the reduction in household labour supply, but we have not disaggregated the recipients at the individual level to see who within the household has reduced the labour supply. Future research on this topic should explore the individual labour supply decisions within the household. This will provide an insight into how individuals within the household alter their labour supply decisions with the arrival of pension. Third, the subsample estimations between men and women program recipients suggest a non-unitary household, but this requires additional empirical work highlighting different behavioural and psychological responses to the pension programme between men and women. 


\section{References}

Abel, M., 2019. Unintended Labor Supply Effects of Cash Transfer Programs: New Evidence from South Africa's Pension. Journal of African Economies, 28(5), pp.558-581.

Alderman, H., Chiappori, P., Haddad, L.,Hoddinott, J., and Kanbur, R. (1995) Unitary versus collective models of the household: is it time to shift the burden of proof?, The World Bank Research Observer 10 (1): 1-19.

Angelucci, M., Attanasio, O. and Di Maro, V., 2012.The impact of Oportunidades on consumption, savings and transfers. Fiscal Studies, 33(3), pp.305-334

Angrist, J.D. and Pischke, J.S., 2008. Mostly harmless econometrics: An empiricist's companion. Princeton university press.

Ardington, C., Case, A. and Hosegood, V., 2009.Labor supply responses to large social transfers: Longitudinal evidence from South Africa. American economic journal: Applied economics, 1(1), pp.22-48.

Asri, V., 2019. Targeting of social transfers: Are India's poor older people left behind?. World Development, 115, pp.46-63.

Attanasio, O. and Mesnard, A., 2006. The impact of a conditional cash transfer programme on consumption in Colombia.Fiscal Studies,27(4), pp.421-442.

Babanezhad, M., Vansteelandt, S., \& Goetghebeur, E. (2010). Comparison of causal effect estimators under exposure misclassification. Journal of Statistical Planning and Inference, 140(5), 1306-1319.

Bastagli, F., Hagen-Zanker, J., Harman, L., Barca, V., Sturge, G., Schmidt, T. and Pellerano, L., 2016. Cash transfers: what does the evidence say. A rigorous review of programme impact and the role of design and implementation features. London: Overseas Development Institute. 
Bobonis, G.J., 2009. Is the allocation of resources within the household efficient? New evidence from a randomized experiment. Journal of Political Economy, 117(3), pp.453-503.

Caliendo, M. and Kopeinig, S., 2008.Some practical guidance for the implementation of propensity score matching. Journal of Economic Surveys,22(1), pp.31-72.

Case, A. and Deaton, A., 1998. Large cash transfers to the elderly in South Africa. The Economic Journal, 108(450), pp.1330-1361.

Case, A. and Menendez, A., 2007. Does money empower the elderly? Evidence from the Agincourt demographic surveillance site, South Africa1.Scandinavian journal of public health, 35(69 suppl), pp.157-164.

Dabalen, A., Kilic, T. and Wane, W., 2008. Social transfers, labor supply and poverty reduction: The case of Albania. The World Bank.

Desai, Sonalde, Reeve Vanneman, and National Council of Applied Economic Research,2005.New Delhi. India Human Development Survey (IHDS), 2005. ICPSR22626v8. Ann Arbor, MI: Inter-university Consortium for Political and Social Research [distributor], 2010-06-29. http://doi.org/10.3886/ICPSR22626.v8

Desai, Sonalde, ReeveVanneman and National Council of Applied Economic Research, New Delhi. India Human Development Survey-II (IHDS-II), 2011-12. ICPSR36151-v2. Ann Arbor, MI: Inter-university Consortium for Political and Social Research [distributor], 2015-07-31. http://doi.org/10.3886/ICPSR36151.v2

Duflo, E., 2003. Grandmothers and granddaughters: old - age pensions and intrahousehold allocation in South Africa. The World Bank Economic Review,17(1), pp.1-25.

Edmonds, E.V., Mammen, K. and Miller, D.L., 2005. Rearranging the family?Income support and elderly living arrangements in a low-income country.Journal of Human resources, 40(1), pp.186-207. 
Galiani, S., Gertler, P. and Schargrodsky, E., 2005. Water for life: The impact of the privatization of water services on child mortality. Journal of Political Economy, 113(1), pp.83-120.

Garroway, C., 2013. How much do small old age pensions and widow's pensions help the poor in India.Development Papers, 1306.

GoI (Government of India), 2016.The Elderly in India, Central Statistic Office, Government of India, New Delhi,

http://www.mospi.gov.in/sites/default/files/publication_reports/ElderlyinIndia_2016.pdf

Haushofer, J., \& Shapiro, J., 2016. The Short-Term Impact of Unconditional Cash Transfers to the Poor: Experimental Evidence from Kenya. The Quarterly Journal of Economics 131(4), 1973-2042.

Heckman, J.J. and Robb Jr, R., 1985. Alternative methods for evaluating the impact of interventions: An overview. Journal of Econometrics, 30(1-2), pp.239-267.

Hirano, K., \&Imbens, G. W. 2001. Estimation of causal effects using propensity score weighting: An application to data on right heart catheterization. Health Services and Outcomes research methodology, 2(3-4), 259-278.

Hirano, K., Imbens, G. W., \& Ridder, G. 2003. Efficient estimation of average treatment effects using the estimated propensity score. Econometrica, 71(4), 1161-1189.

ILO (International Labour Organisation), 2016. India Labour Market Update, July 2016. Accessed on 20 September 2019 from http://www.ilo.org/wcmsp5/groups/public/---asia/--ro-bangkok/---sro-new_delhi/documents/publication/wcms_496510.pdf

Imai, K.S. and Azam, M.S., 2012. Does microfinance reduce poverty in Bangladesh? New evidence from household panel data. Journal of Development studies, 48(5), pp.633-653.

Kaushal, N., 2014. How public pension affects elderlylabor supply and well-being: Evidence from India. World Development, 56, pp.214-225. 
Kidd and Whitehouse 2009.. Closing the coverage gap: Role of social pensions and other retirement income transfers. World Bank Publications edited by Holzmann, R., Robalino, D.A. and Takayama, pp 41-56

Kim, M.H., Kim, C.Y., Park, J.K. and Kawachi, I., 2008. Is precarious employment damaging to self-rated health? Results of propensity score matching methods, using longitudinal data in South Korea. Social science \& medicine,67(12), pp.1982-1994.

Lena, A., Ashok, K., Padma, M., Kamath, V. and Kamath, A., 2009. Health and social problems of the elderly: A cross-sectional study in Udupi Taluk, Karnataka. Indian Journal of Community Medicine, 34(2), p.131.

Leuven, E., and Sianesi, B. (2003). "PSMATCH2: Stata module to perform full Mahalanobis and propensity score matching, common support graphing, and covariate imbalance testing" http://ideas.repec.org/c/boc/bocode/s432001.html.

Linden, A., \& Adams, J. L. (2010). Evaluating health management programmes over time: application of propensity score - based weighting to longitudinal data. Journal of Evaluation in Clinical Practice, 16(1), 180-185.

Michalopoulos, C., Bloom, H. S., \& Hill, C. J. (2004). Can propensity-score methods match the findings from a random assignment evaluation of mandatory welfare-to-work programs?.Review of Economics and Statistics, 86(1), 156-179.

Narayanan, S., 2011. A case for reframing the cash transfer debate in India. Economic and Political Weekly,Vol. 46, No. 21, pp.41-48.

Ning, M., Gong, J., Zheng, X. and Zhuang, J., 2016. Does New Rural Pension Scheme decrease elderlylabor supply? Evidence from CHARLS.China Economic Review, 41, pp.315-330.

Pal, S. and Palacios, R., 2011. Understanding poverty among the elderly in India: Implications for social pension policy. Journal of Development Studies, 47(7), pp.1017-1037. 
Posel, D., Fairburn, J.A. and Lund, F., 2006. Labour migration and households: A reconsideration of the effects of the social pension on labour supply in South Africa. Economic modelling, 23(5), pp.836-853.

Randive, B., Diwan, V. and De Costa, A., 2013. India's Conditional Cash Transfer Programme (the JSY) to promote institutional birth: Is there an association between institutional birth proportion and maternal mortality?.PloS one, 8(6), p.e67452.

Rajan, S.I., 2001. Social assistance for poor elderly: How effective?.Economic and Political Weekly, Vol. 36, No. 8, pp.613-617.

Rosenbaum, P.R. and Rubin, D.B., 1984. Reducing bias in observational studies using subclassification on the propensity score. Journal of the American statistical Association, 79(387), pp.516-524.

Rubin, D. B. (2001). Using propensity scores to help design observational studies: application to the tobacco litigation. Health Services and Outcomes Research Methodology, 2(3-4), 169188.

Ryan, A.M., Kontopantelis, E., Linden, A. and Burgess Jr, J.F., 2019.Now trending: Coping with non-parallel trends in difference-in-differences analysis. Statistical methods in medical research, 28(12), pp.3697-3711.

Singh, A. and Das, U., 2015. Increasing Compulsion to Work for Wages: Old Age Labor Participation and Supply in India over the Past Two Decades.Journal of Population Ageing, 8(4), pp.303-326.

Skoufias, E. and Di Maro, V., 2008. Conditional cash transfers, adult work incentives, and poverty. The Journal of Development Studies, 44(7), pp.935-960.

Thomas, D., 1990. Intra-household resource allocation: An inferential approach. Journal of human resources, pp.635-664. 
Uppal, S. and Sarma, S., 2007. Aging, health and labour market activity: the case of India. World health \& population, 9(4), pp.79-97.

WHO, 2010. India tries to break cycle of health-care debt. Bulletin of the World Health Organization Past 88(7), pp. 481-560 (http://www.who.int/bulletin/volumes/88/7/10020710.pdf?ua=1). 
Table 1: Summary statistics on weighted matched panel

\begin{tabular}{|c|c|c|c|c|c|c|}
\hline \multirow[t]{3}{*}{ Variables } & \multicolumn{3}{|c|}{$2004-5$} & \multicolumn{3}{|c|}{ 2011-12 } \\
\hline & \multicolumn{2}{|c|}{ Mean } & \multirow[t]{2}{*}{ F-stat } & \multicolumn{2}{|c|}{ Mean } & \multirow[t]{2}{*}{ F-stat } \\
\hline & $\begin{array}{c}\text { Pension } \\
\text { non- } \\
\text { receiving } \\
\text { households } \\
(\mathrm{N}=36,983)\end{array}$ & $\begin{array}{c}\text { Pension } \\
\text { receiving } \\
\text { household } \\
(\mathrm{N}= \\
1,326)\end{array}$ & & $\begin{array}{c}\text { Pension } \\
\text { non- } \\
\text { receiving } \\
\text { households } \\
(\mathrm{N}=34,610)\end{array}$ & $\begin{array}{c}\text { Pension } \\
\text { receiving } \\
\text { household } \\
(\mathrm{N}= \\
3,699)\end{array}$ & \\
\hline \multicolumn{7}{|l|}{ Outcome variables } \\
\hline MPCE [1] & 722.7 & 720.95 & 0.01 & 1806.45 & 1711.6 & $11.82^{\star \star}$ \\
\hline MPCE (food) [2] & 302.87 & 312.73 & $4.34^{*}$ & 733.12 & 719.77 & 3.76 \\
\hline MPCE (non-food) [3] & 178.49 & 169.47 & 2.69 & 491.82 & 472.02 & 3 \\
\hline Assets[4] & 10.43 & 11.22 & $23.37^{\star * *}$ & 12.92 & 12.76 & 2.61 \\
\hline Number of household members working & 2.77 & 2.72 & 0.97 & 2 & 1.94 & $4.55^{*}$ \\
\hline Poor $[5]$ & 0.28 & 0.25 & $6.8^{*}$ & 0.24 & 0.23 & 0.56 \\
\hline Household income (excluding IGNOAPS) [6] & 48603.2 & 51259.2 & 2.02 & 56723.8 & 49334.4 & $13.32^{* * *}$ \\
\hline IGNOAPS amount (annually) & nil & 2242 & nil & nil & 2548.43 & nil \\
\hline
\end{tabular}

Explanatory variables used in probit model to derive propensity score model

\begin{tabular}{|c|c|c|c|c|c|c|}
\hline BPL card & 0.43 & 0.42 & 0.34 & - & - & - \\
\hline Antyodaya card & 0.06 & 0.05 & $4.95^{\star}$ & - & - & - \\
\hline Household: elderly & 0.95 & 0.95 & 0.08 & 0.92 & 0.93 & 1.01 \\
\hline Rural area \& attends public meeting & 0.31 & 0.31 & 0.07 & 0.31 & 0.31 & 0.61 \\
\hline Highest education in the household & 6.11 & 6.54 & $9.63^{*}$ & 6.54 & 6.71 & 3.41 \\
\hline Scheduled caste or tribe & 0.4 & 0.4 & 0 & 0.36 & 0.36 & 0.7 \\
\hline Women:TV & - & - & - & 0.68 & 0.7 & 2.62 \\
\hline Household has a BPL or Antyodaya card & - & - & - & 0.66 & 0.66 & 0.07 \\
\hline Urban area & 0.21 & 0.13 & $54.38^{* * *}$ & 0.23 & 0.18 & $73.26^{\star \star \star}$ \\
\hline Women: newspaper & 0.23 & 0.19 & $12.66^{* * *}$ & 0.24 & 0.22 & 3.16 \\
\hline Women : TV & 0.61 & 0.58 & $6.75^{\star}$ & & & \\
\hline of other welfare programs received by household [7] & 0.09 & 0.07 & $4.22^{*}$ & 0.2 & 0.09 & $382.99^{* * *}$ \\
\hline
\end{tabular}


Hindu

0.83

0.86

$5.83^{*}$

0.83

0.85

$8.68^{\star *}$

Household composition/size excluding elderly and children

3.24

Number of children

1.95

3.19

0.77

2.58

2.53

Number of elderly male

0.62

2.02

1.33

$0.587 .52^{*}$

0.55

$113.88^{\star \star \star}$

0.63

Number of elderly female

\section{Notes}

[1] IHDS has constructed the monthly expenditure using a broad range of variables which represents the purchasing power capacity of the household. The list of items included in the food and non-food categories are only a subset of the total expenditure incurred.

[2] Food expenditure includes spending on Rice, Wheat, Sugar, Other cereals, Cereal products, Pulses, Meat, Sweeteners, Edible oil, Eggs, Milk, Milk Products, Vegetables, Fruits/nuts, Salt/spices and Other food.

[3] Non-food expenditure includes Paan/tobacco/intoxicants, Restaurants/Eating out, Entertainment, Telephone/Cable/Internet charges, Toiletries, Transportation, Consumer taxes/fees, Services (domestic servants, barber, laundry, etc.) and Medical (out-patient services)

[4] The assets index used here remains the same for 2004-5 and 2011-12. The assets include any vehicle, Sewing machine, Mixer/grinder, Motor vehicle, any TV, Colour TV, Air cooler/cond, Clock/watch, Electric fan, Chair/table, Cot, Telephone, Cell phone, Refrigerator, Pressure cooker, Car, Air conditioner, Washing machine Computer, Credit card, 2 clothes, Footwear, Piped indoor water, Separate kitchen, Flush toilet, Electricity, LPG, Pucca wall, Pucca roof and Pucca floor.

[5] We have used the poor variable as defined by IHDS. 2005. See Endnote 12 for its definition.

[6] IHDS has enquired about different sources of income. The total income variable is calculated from the income in farms, agricultural wages, non-agricultural sources, salary, business, remittances, government benefits and other sources. We have deducted the payment received from IGNOAPS from this.

[7] Other welfare programs include Widow Benefits, Disability benefits, Annapurna benefits, other income benefits, NGO benefits and Maternity benefits.

${ }^{*} p<0.05,{ }^{* *} p<0.01,{ }^{* * *} p<0.001$ 
Table 2: Effects of IGNOAPS participation on household welfare and poverty (based on FE models with PS weighting applied to the matched panel data)

\begin{tabular}{|c|c|c|c|c|c|c|c|}
\hline Variables & $\begin{array}{l}\text { Log real } \\
\text { MPCE } \\
\text { [1] }\end{array}$ & $\begin{array}{l}\text { Log real } \\
\text { MPCE(food) } \\
\text { [2] }\end{array}$ & $\begin{array}{l}\text { Log real } \\
\text { MPCE } \\
\text { (non-food) } \\
{[3]}\end{array}$ & $\begin{array}{l}\text { Log } \\
\text { assets } \\
\text { index } \\
{[4]}\end{array}$ & $\begin{array}{l}\text { Log } \\
\text { number of } \\
\text { household } \\
\text { members } \\
\text { working }\end{array}$ & $\begin{array}{l}\text { Poor } \\
\text { [5] }\end{array}$ & $\begin{array}{l}\text { Log real } \\
\text { household } \\
\text { Income } \\
\text { excluding } \\
\text { IGNOAPS } \\
\text { [6] }\end{array}$ \\
\hline \multicolumn{8}{|l|}{$\begin{array}{l}\text { Fixed-effects model applied to the matched } \\
\text { panel data with PS weighting }\end{array}$} \\
\hline $\begin{array}{l}\left.\text { Household } \quad \text { receiving }_{(\text {Yes/No })(I G N O A P S} \text { recipient }_{h t}\right)\end{array}$ & $\begin{array}{c}0.0549^{* *} \\
(0.01)\end{array}$ & $\begin{array}{c}0.0575^{\star * *} \\
(0.01)\end{array}$ & $\begin{array}{c}0.0874^{* *} \\
(0.03)\end{array}$ & $\begin{array}{c}0.100^{* * *} \\
(0.01)\end{array}$ & $\begin{array}{c}-0.099^{* * *} \\
(0.01)\end{array}$ & $\begin{array}{c}0.0124 \\
(0.01)\end{array}$ & $\begin{array}{l}-0.011 \\
(0.03)\end{array}$ \\
\hline Control variables included [8] & Yes & Yes & Yes & Yes & Yes & Yes & Yes \\
\hline Observations & 76,536 & 76,518 & 76,448 & 76,499 & 72,186 & 76,562 & 75,233 \\
\hline Household fixed effects & Yes & Yes & Yes & Yes & Yes & Yes & Yes \\
\hline Number of Households & 38309 & 38308 & 38309 & 38308 & 37786 & 38309 & 38267 \\
\hline R-squared & 0.888 & 0.886 & 0.85 & 0.932 & 0.897 & 0.843 & 0.897 \\
\hline
\end{tabular}

Notes

[1] IHDS has constructed the monthly expenditure using a broad range of variables which represents the purchasing power capacity of the household. The list of items included in the food and non-food categories are only a subset of the total expenditure incurred. [2] Food expenditure includes spending on Rice, Wheat, Sugar, Other cereals, Cereal products, Pulses, Meat, Sweeteners, Edible oil, Eggs, Milk, Milk Products, Vegetables, Fruits/nuts, Salt/spices and Other food. ge, Mik, Milk Products, Vegetables, Fruits/nuts, Saltspices and Otherfood.

[3] Non-food expenditure includes Paan/tobacco/intoxicants, Restaurants/Eating out, Entertainment, Telephone/Cable/Internet charges, Toiletries, Transportation, Consumer taxes/fees, Services (domestic servants, barber, laundry, etc.) and Medical (out-patient

[4] The assets index used here remains the same for 2004-5 and 2011-12. The assets include any vehicle, Sewing machine Mixer/grinder, Motor vehicle, any TV, Colour TV, Air cooler/cond, Clock/watch, Electric fan, Chair/table, Cot, Telephone, Cell phone, 
Refrigerator, Pressure cooker, Car, Air conditioner, Washing machine, Computer, Credit card, 2 clothes, Footwear, Piped indoor water, Separate kitchen, Flush toilet, Electricity, LPG, Pucca wall, Pucca roof and Pucca floor.

5] We have used the poor variable as defined by IHDS. 2005. See Endnote 12 for its definition.

[6] IHDS has enquired about different sources of income. The total income variable is calculated from the income in farms, agricultural wages, non-agricultural sources, salary, business, remittances, government benefits and other sources. We have deducted the payment received from IGNOAPS from this.

[8]The control variables included here are household size excl.children and elderly, number of children, number of elderly male number of elderly female, the highest level of education in the household, urban area, women: newspaper, women: TV, household head being a Hindu, caste, and other welfare programs received by the household.

[9] Robust standard errors in parentheses, ${ }^{*} p<0.05,{ }^{* *} p<0.01,{ }^{* * *} p<0.001$

Source: Authors' estimations based on IHDS data. 
Table 3: The results of extensions and sub-sample estimations (based on the FE model using matched panel with PS weighting)

\begin{tabular}{|c|c|c|c|c|c|c|c|c|}
\hline Variables & $\begin{array}{l}\text { Elderly } \\
\text { labour } \\
\text { supply }\end{array}$ & $\begin{array}{l}\text { Log real } \\
\text { MPCE }\end{array}$ & $\begin{array}{l}\text { Log real } \\
\text { MPCE } \\
\text { (food) }\end{array}$ & $\begin{array}{l}\text { Log real } \\
\text { MPCE } \\
\text { (non-food) }\end{array}$ & $\begin{array}{l}\text { Log } \\
\text { assets } \\
\text { index }\end{array}$ & $\begin{array}{l}\text { Log } \\
\text { number of } \\
\text { household } \\
\text { members } \\
\text { working }\end{array}$ & Poor & $\begin{array}{l}\text { Log } \\
\text { household } \\
\text { income } \\
\text { excluding } \\
\text { IGNOAPS }\end{array}$ \\
\hline \multicolumn{9}{|l|}{$\begin{array}{l}\text { Fixed-effects model applied to } \\
\text { matched panel with PS weighting }\end{array}$} \\
\hline $\begin{array}{l}\text { Household with IGNOAPS recipient } \\
\left.\text { (Yes/No)(IGNOAPS recipient }{ }_{h t}\right)\end{array}$ & $\begin{array}{l}-0.127^{* * *} \\
(0.01)\end{array}$ & & & & & & & \\
\hline $\begin{array}{l}\text { Observations } \\
\text { Number of Households } \\
\text { R-squared } \\
\text { Control variables } \\
\text { Household fixed effects }\end{array}$ & $\begin{array}{l}76,618 \\
38309 \\
0.848 \\
\text { Yes } \\
\text { Yes }\end{array}$ & & & & & & & \\
\hline $\begin{array}{l}\text { Household with male receiving } \\
\text { IGNOAPS } \\
\left.\text { (Yes/No)(IGNOAPS male recipient }{ }_{h t}\right)\end{array}$ & & $\begin{array}{l}0.0165 \\
(0.02)\end{array}$ & $\begin{array}{l}0.0307 \\
(0.02)\end{array}$ & $\begin{array}{l}0.0179 \\
(0.04)\end{array}$ & $\begin{array}{c}0.0507^{*} \\
(0.02)\end{array}$ & $\begin{array}{l}-0.0326 \\
(0.02)\end{array}$ & $\begin{array}{l}0.0122 \\
(0.02)\end{array}$ & $\begin{array}{c}0.0339 \\
(0.05)\end{array}$ \\
\hline $\begin{array}{l}\text { Observations } \\
\text { Number of Households } \\
\text { R-squared } \\
\text { Control variables } \\
\text { Household fixed effects }\end{array}$ & & $\begin{array}{c}74401 \\
38154 \\
0.89 \\
\text { Yes } \\
\text { Yes }\end{array}$ & $\begin{array}{l}74382 \\
38153 \\
0.892 \\
\text { Yes } \\
\text { Yes }\end{array}$ & $\begin{array}{l}74314 \\
38150 \\
0.859 \\
\text { Yes } \\
\text { Yes }\end{array}$ & $\begin{array}{l}74363 \\
38150 \\
0.935 \\
\text { Yes } \\
\text { Yes }\end{array}$ & $\begin{array}{l}70294 \\
37576 \\
0.899 \\
\text { Yes } \\
\text { Yes }\end{array}$ & $\begin{array}{l}74425 \\
38156 \\
0.850 \\
\text { Yes } \\
\text { Yes }\end{array}$ & $\begin{array}{l}73195 \\
38076 \\
0.898 \\
\text { Yes } \\
\text { Yes }\end{array}$ \\
\hline $\begin{array}{l}\text { Household with female receiving } \\
\text { IGNOAPS } \\
\left.\text { (Yes/No)(IGNOAPS female recipient } t_{h t}\right)\end{array}$ & & $\begin{array}{c}0.0593^{*} \\
(0.02)\end{array}$ & $\begin{array}{c}0.0726^{\star *} \\
(0.02)\end{array}$ & $\begin{array}{l}0.017 \\
(0.04)\end{array}$ & $\begin{array}{l}0.0743^{\star * *} \\
(0.02)\end{array}$ & $\begin{array}{l}-0.0315 \\
(0.02)\end{array}$ & $\begin{array}{c}0.0332 \\
(0.02)\end{array}$ & $\begin{array}{l}0.0489 \\
(0.04)\end{array}$ \\
\hline $\begin{array}{l}\text { Observations } \\
\text { Number of Households } \\
\text { R-squared } \\
\text { Control variables } \\
\text { Household fixed effects }\end{array}$ & & $\begin{array}{l}74,534 \\
38215 \\
0.889 \\
\text { Yes } \\
\text { Yes }\end{array}$ & $\begin{array}{l}74,518 \\
38214 \\
0.889 \\
\text { Yes } \\
\text { Yes }\end{array}$ & $\begin{array}{l}74,448 \\
38211 \\
0.853 \\
\text { Yes } \\
\text { Yes }\end{array}$ & $\begin{array}{l}74,501 \\
38208 \\
0.934 \\
\text { Yes } \\
\text { Yes }\end{array}$ & $\begin{array}{l}70,373 \\
37647 \\
0.901 \\
\text { Yes } \\
\text { Yes }\end{array}$ & $\begin{array}{l}74,559 \\
38215 \\
0.85 \\
\text { Yes } \\
\text { Yes }\end{array}$ & $\begin{array}{c}73,302 \\
38126 \\
0.90 \\
\text { Yes } \\
\text { Yes }\end{array}$ \\
\hline
\end{tabular}


Sub-sample estimation on

households with a political

connection:

Households with IGNOAPS recipient

(Yes/No)(IGNOAPS recipient $\left.{ }_{h t}\right)$

0.006
$(0.642)$

0.0581
$(0.526)$

0.0901
$(0.811)$

0.196

$-0.373$

$\begin{array}{ll}0.0538 & -0.530 \\ (0.529) & (1.062)\end{array}$

Observations

Number of Households

Control variables

R-squared

Household fixed effects

$\begin{array}{cc}5292 & 5293 \\ 5060 & 5061 \\ \text { Yes } & \text { Yes } \\ 0.991 & 0.992 \\ \text { Yes } & \text { Ye }\end{array}$

5293
5061
Yes
0.992
Yes

5258

$\quad(0.539)$

$5293 \quad 5171$

Sub-sample estimation on

households head belonging to

Scheduled Caste or Tribe:

Households with IGNOAPS recipient

(Yes/No)(IGNOAPS recipient ${ }_{h t}$ )

0.0315

0.0498

$(0.03) \quad(0.02)$

0.052

5058

5096

50614952

$\begin{array}{lllll}\text { Yes } & \text { Yes } & \text { Yes } & \text { Yes } & \text { Yes } \\ 0.991 & 0.997 & 0.992 & 0.991 & 0.992\end{array}$

$\begin{array}{lllll}0.991 & 0.997 & 0.992 & 0.991 & 0.992\end{array}$

Observations

Number of Households

R-squared

Control variables

Household fixed effects

$23,675 \quad 23,676$

$13083 \quad 13082$

$0.887 \quad 0.885$

$(0.05)$

$(0.02)$

$-0.0892^{* *}$

0.0169

$\begin{array}{lll}(0.02) & (0.02) & 0.0844 \\ & (0.05)\end{array}$

23,645

$23615 \quad 22,848 \quad 23,683$

$\begin{array}{llll}13079 & 12894 & 13083 & 23,396\end{array}$

$\begin{array}{lllll}0.84 & 0.917 & 0.899 & 0.842 & 13048\end{array}$

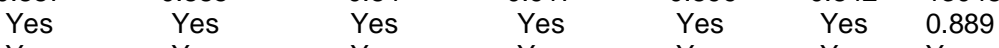

Yes Yes Yes Yes Yes Yes Yes

Robust standard errors in parentheses, ${ }^{*} p<0.05,{ }^{* \star} p<0.01,{ }^{* * *} p<0.001$

Source: Authors' estimations based on IHDS data. 
Table 4: The results of the model to examine the programme change of IGNOAPS based on the FE model with PSM with PS weighting (Dependent variable: whether a household received in IGNOAPS)

\begin{tabular}{|c|c|c|c|c|c|c|c|}
\hline Variables & $\begin{array}{l}\text { Log real } \\
\text { MPCE }\end{array}$ & $\begin{array}{l}\text { Log real } \\
\text { MPCE } \\
\text { (food) }\end{array}$ & $\begin{array}{l}\text { Log real } \\
\text { MPCE } \\
\text { (non-food) }\end{array}$ & $\begin{array}{l}\text { Log } \\
\text { assets index }\end{array}$ & $\begin{array}{l}\text { Log number of } \\
\text { household } \\
\text { members } \\
\text { working }\end{array}$ & Poor & $\begin{array}{l}\text { Log } \\
\text { household } \\
\text { income } \\
\text { excluding } \\
\text { IGNOAPS }\end{array}$ \\
\hline \multicolumn{8}{|c|}{$\begin{array}{l}\text { Case without the households who received IGNOAPS in } 2004 \\
\text { Household receiving IGNOAPS (Yes/No) } \\
\text { (newIGNOAPS recipient }{ }_{h t} \text { ) }\end{array}$} \\
\hline & $\begin{array}{l}-0.004 \\
(0.02)\end{array}$ & $\begin{array}{c}-0.0129 \\
(0.01)\end{array}$ & $\begin{array}{c}-0.0043 \\
(0.03)\end{array}$ & $\begin{array}{c}0.0474^{\star *} \\
(0.01)\end{array}$ & $\begin{array}{c}-0.0484^{*} \\
(0.02)\end{array}$ & $\begin{array}{c}0.00969 \\
(0.01)\end{array}$ & $\begin{array}{c}-0.129^{* *} \\
(0.04)\end{array}$ \\
\hline Program expansion (year dummy) & $\begin{array}{c}0.208^{* * *} \\
(0.01)\end{array}$ & $\begin{array}{c}0.181^{* * *} \\
(0.00)\end{array}$ & $\begin{array}{c}0.405^{\star * *} \\
(0.01)\end{array}$ & $\begin{array}{c}0.254^{* * *} \\
(0.00)\end{array}$ & $\begin{array}{c}-0.168^{\star * *} \\
(0.00)\end{array}$ & $\begin{array}{l}0.004 \\
(0.00)\end{array}$ & $\begin{array}{c}0.265^{\star * *} \\
(0.01)\end{array}$ \\
\hline Control variables & Yes & Yes & Yes & Yes & Yes & Yes & Yes \\
\hline Household fixed effects & Yes & Yes & Yes & Yes & Yes & Yes & Yes \\
\hline $\begin{array}{l}\text { Observations } \\
\text { R-squared }\end{array}$ & $\begin{array}{c}75212 \\
0.914\end{array}$ & $\begin{array}{l}75195 \\
0.918\end{array}$ & $\begin{array}{c}75127 \\
0.886\end{array}$ & $\begin{array}{l}75176 \\
0.957\end{array}$ & $\begin{array}{c}70942 \\
0.922\end{array}$ & $\begin{array}{l}75238 \\
0.872\end{array}$ & $\begin{array}{l}73955 \\
0.919\end{array}$ \\
\hline
\end{tabular}

Robust standard errors in parentheses, ${ }^{* * *} p<0.01,{ }^{* *} p<0.05,{ }^{*} p<0.1$. Source: Authors' estimations based on IHDS data.

${ }^{*} p<0.05,{ }^{* *} p<0.01,{ }^{* * *} p<0.001$ 
Figure 1: Regions in common support 2004-5

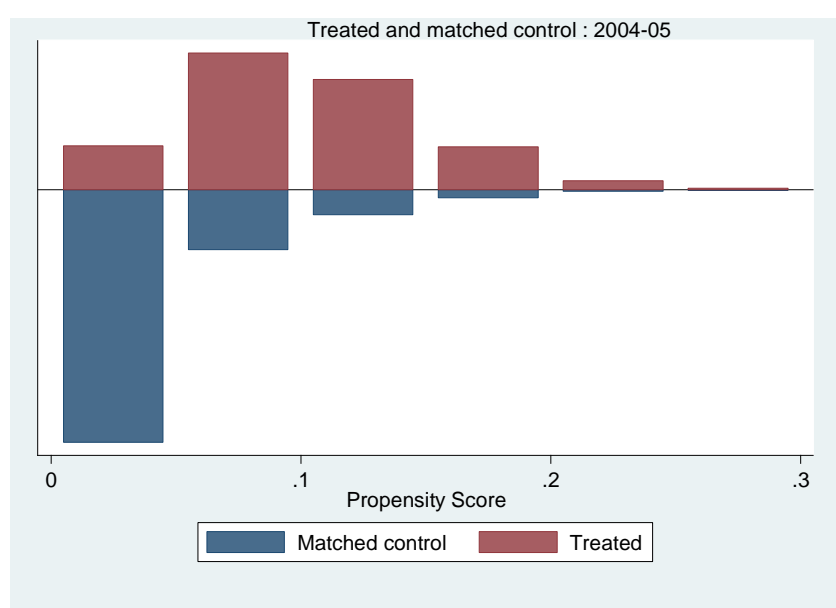

Source: Authors' calculations based on IHDS data.

Figure 2: Regions in commonsupport 2011-12

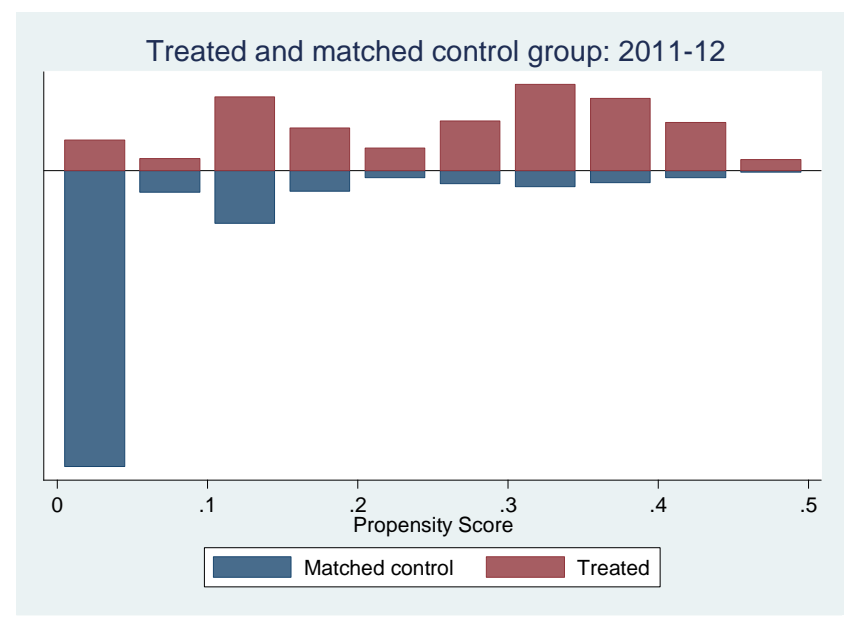

Source: Authors' calculations based on IHDS data. 
Figure 3: PS match in 2004-5

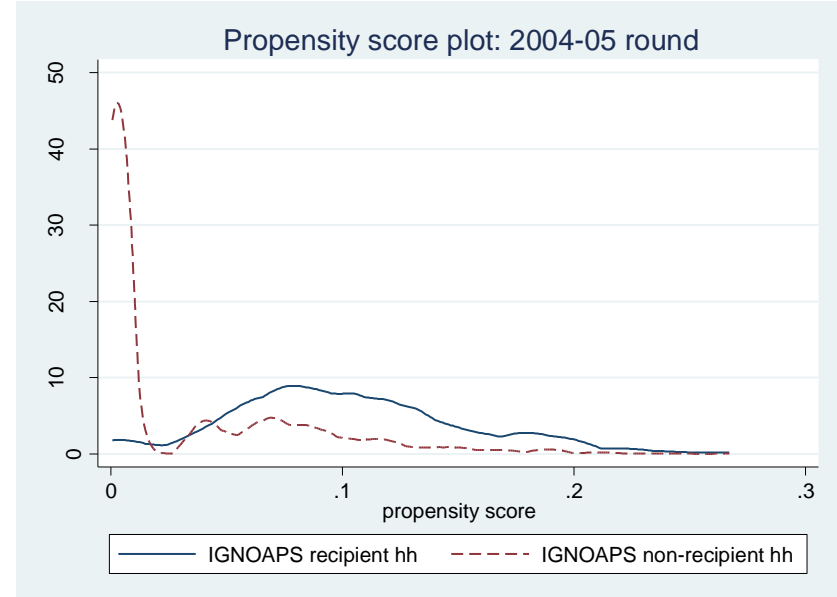

Source: Authors' calculations based on IHDS data.

\section{Figure 4: PS match in 2011-12}

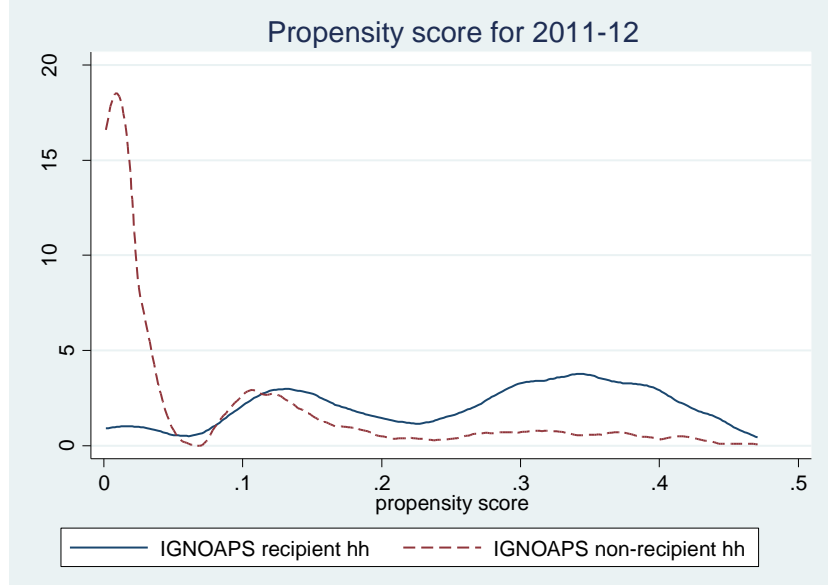

Source: Authors' calculations based on IHDS data. 
Appendix 1: Amount of pension, state contribution and eligibility criteria used

\begin{tabular}{llcc}
\hline States/UTs & Central & Contribution of & Eligibility criteria used * \\
& Assistance under & State Govt. per & Number of \\
& IGNOAPS- & beneficiary per & month \\
& Monthly & (Rs, 2011) & $($ Rs,2011)
\end{tabular}

\begin{tabular}{|c|c|c|c|c|c|}
\hline 1 & Andhra Pradesh & 200 & Nil & & $1,011,153$ \\
\hline 2 & Bihar & 200 & Nil & $\begin{array}{c}\text { BPL card holders with an } \\
\text { annual income of less than } \\
\text { Rs. } 30,000\end{array}$ & $2,369,656$ \\
\hline 3 & Chhattisgarh & 200 & 100 & $\mathrm{n} / \mathrm{a}$ & 533,665 \\
\hline 4 & Goa & 200 & 800 & $\mathrm{n} / \mathrm{a}$ & 2,734 \\
\hline 5 & Gujarat & 200 & 200 & $\mathrm{n} / \mathrm{a}$ & 279,834 \\
\hline 6 & Haryana & 200 & $\begin{array}{c}300 \text { for } 70 \text { years and } \\
500 \text { for above } 70 \\
\text { years }\end{array}$ & $\begin{array}{c}\text { Age, Income }<\text { Rs. } 50000 \\
\text { per annum }\end{array}$ & 130,306 \\
\hline 7 & Himachal Pradesh & 200 & 130 & Age, BPL & 91,440 \\
\hline 8 & $\begin{array}{l}\text { Jammu and } \\
\text { KAshmir }\end{array}$ & 200 & 125 & $\begin{array}{l}\text { Age of proof (date of birth } \\
\text { /age certificate) Income } \\
\text { certificate/ BPL certificate }\end{array}$ & 129,000 \\
\hline 9 & Jharkhand & 200 & 200 & $\mathrm{n} / \mathrm{a}$ & 676,003 \\
\hline 10 & Karnataka & 200 & 200 & $\mathrm{n} / \mathrm{a}$ & 797,862 \\
\hline 11 & Kerala & 200 & 50 & $\mathrm{n} / \mathrm{a}$ & 176,064 \\
\hline 12 & Madhya Pradesh & 200 & 75 & $\mathrm{n} / \mathrm{a}$ & $1,061,033$ \\
\hline 13 & Maharashtra & 200 & 400 & Age, BPL & $1,057,510$ \\
\hline 14 & Orissa & 200 & Nil & $\mathrm{n} / \mathrm{a}$ & $1,193,176$ \\
\hline 15 & Punjab & 200 & 250 & $\mathrm{n} / \mathrm{a}$ & 159,792 \\
\hline 16 & Rajasthan & 200 & $\begin{array}{c}300 \text { for } 70 \text { years or } \\
\text { below and } 550 \text { for } \\
\text { above } 70 \text { years }\end{array}$ & $\begin{array}{l}\text { The lowest age eligibility } \\
\text { criterion } 55 \text { years for } \\
\text { female and } 58 \text { years for } \\
\text { female }\end{array}$ & 527,636 \\
\hline 17 & Tamil Nadu & 200 & 800 & Age, BPL & 995,237 \\
\hline 18 & Uttar Pradesh & 200 & 100 & $\begin{array}{l}\text { Age, for rural: BPL; for } \\
\text { urban: BPL/AAY card } \\
\text { holder/name appears on } \\
\text { the survey list of District } \\
\text { Urban Development } \\
\text { Authority or Ministry of } \\
\text { Urban Development } \\
\text { (MoUD) BPL list }\end{array}$ & $3,274,780$ \\
\hline 19 & Uttarakhand & 200 & 200 & Age & 183,501 \\
\hline 20 & West Bengal & 200 & 200 & $\mathrm{n} / \mathrm{a}$ & $1.679,381$ \\
\hline
\end{tabular}




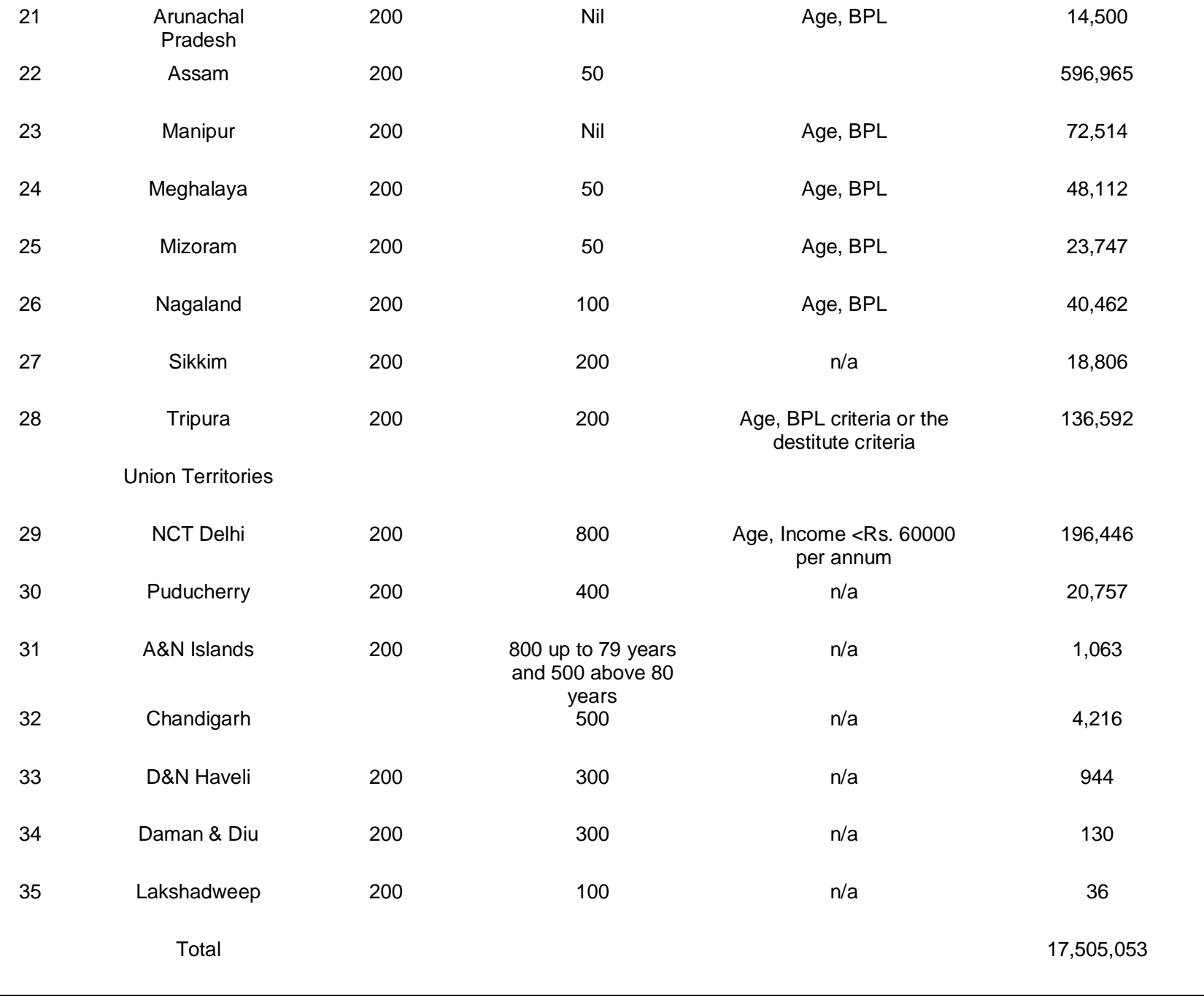

Sources: http://socialjustice.nic.in/pdf/ar12eng.pdf, ${ }^{*}$ Identity criteria havebeen taken from numerous sources, which includes Government websites, https://ifrogs.org/EVENTS/PRESENTATIONS/sI_Rinku20150224_pensionworkshop.pdf, and helpageindia sources 


\section{Appendix 2: Definition of variables}

\begin{tabular}{|c|c|c|}
\hline Variables & Definition & $\begin{array}{l}\text { Constructed variable or } \\
\text { available in IHDS }\end{array}$ \\
\hline BPL card & $\begin{array}{l}\text { Household has a BPL } \\
\text { card }\end{array}$ & Available in IHDS \\
\hline Antyodaya card & $\begin{array}{l}\text { Household has an } \\
\text { Antyodaya card }\end{array}$ & Available in IHDS \\
\hline Household has a BPL or Antyodaya card & $\begin{array}{l}\text { If the household has } \\
\text { either a BPLor Antyodaya } \\
\text { card }\end{array}$ & Constructed from above \\
\hline Household: elderly & $\begin{array}{l}\text { If the household has an } \\
\text { elderly member (age } 60 \\
\text { years or more) }\end{array}$ & Constructed \\
\hline Rural area \& attends public meeting & $\begin{array}{l}\text { Household lives in a rural } \\
\text { area \& attends a public } \\
\text { meeting }\end{array}$ & Constructed \\
\hline MPCE[1] & $\begin{array}{l}\text { Monthly per capita } \\
\text { consumption expenditure }\end{array}$ & Available in IHDS \\
\hline MPCE (food)[2] & $\begin{array}{l}\text { Monthly per capita food } \\
\text { expenditure }\end{array}$ & Available in IHDS \\
\hline MPCE (non-food)[3] & $\begin{array}{l}\text { Monthly per capita non- } \\
\text { food expenditure }\end{array}$ & Available in IHDS \\
\hline Assets[4] & $\begin{array}{l}\text { Number of household } \\
\text { assets }\end{array}$ & Available in IHDS \\
\hline Poor[5] & $\begin{array}{l}\text { If the household is } \\
\text { classified poor }\end{array}$ & Available in IHDS \\
\hline Household Income excluding IGNOAPS [6] & $\begin{array}{l}\text { Annual Income of the } \\
\text { household after removing } \\
\text { transfers received from } \\
\text { IGNOAPS }\end{array}$ & Constructed \\
\hline Number of household members working & $\begin{array}{l}\text { Number of household } \\
\text { members working }\end{array}$ & Available in IHDS \\
\hline $\begin{array}{l}\text { Household composition/size excluding } \\
\text { elderly and children }\end{array}$ & $\begin{array}{l}\text { Number of persons in the } \\
\text { household excluding the } \\
\text { number of elderly and } \\
\text { children }\end{array}$ & Constructed \\
\hline Number of elderly male & $\begin{array}{l}\text { Number of elderly male in } \\
\text { the household }\end{array}$ & $\begin{array}{l}\text { Constructed for the } 2005 \\
\text { round/available in the } \\
2011-12 \text { rounds }\end{array}$ \\
\hline Number of elderly female & $\begin{array}{l}\text { Number of elderly female } \\
\text { in the household }\end{array}$ & $\begin{array}{l}\text { Constructed for the } 2005 \\
\text { round/available in the } \\
2011-12 \text { rounds }\end{array}$ \\
\hline Number of children & $\begin{array}{l}\text { Number of children in the } \\
\text { household }\end{array}$ & $\begin{array}{l}\text { Available in the } 2005 \\
\text { rounds/constructed for the } \\
2011-12 \text { round }\end{array}$ \\
\hline Highest education in the household & & Available in IHDS \\
\hline
\end{tabular}




\begin{tabular}{|c|c|c|}
\hline & $\begin{array}{l}\text { Highest adult education } \\
\text { (number of years) in the } \\
\text { household. }\end{array}$ & \\
\hline Urban area & $\begin{array}{l}\text { If the household lives in } \\
\text { an urban area }\end{array}$ & Available in IHDS \\
\hline Women: newspaper & $\begin{array}{l}\text { If the women in the } \\
\text { household have access to } \\
\text { newspaper }\end{array}$ & Available in IHDS \\
\hline Women: TV & $\begin{array}{l}\text { If the women in the } \\
\text { household have access to } \\
\text { TV }\end{array}$ & Available in IHDS \\
\hline Scheduled caste & $\begin{array}{l}\text { If the household head } \\
\text { belongs to Scheduled } \\
\text { Caste }\end{array}$ & Available in IHDS \\
\hline Scheduled tribe & $\begin{array}{l}\text { If the household head } \\
\text { belongs to Scheduled } \\
\text { Tribe }\end{array}$ & Available in IHDS \\
\hline Scheduled caste or tribe & $\begin{array}{l}\text { If the household head } \\
\text { belongs to Scheduled } \\
\text { caste or tribe }\end{array}$ & Constructed from above \\
\hline $\begin{array}{l}\text { Number of other welfare programs received by the } \\
\text { household [7] }\end{array}$ & $\begin{array}{l}\text { Other welfare programs } \\
\text { received }\end{array}$ & Constructed \\
\hline Hindu & $\begin{array}{l}\text { If the household head } \\
\text { belongs to Hindu religion }\end{array}$ & Constructed \\
\hline IGNOAPS amount & $\begin{array}{l}\text { Amount received in } \\
\text { IGNOAPS (annually) }\end{array}$ & Available in IHDS \\
\hline
\end{tabular}

[1] IHDS has constructed the monthly expenditure using a broad range of variables which represents the purchasing power capacity of the household. The list of items included in the food and non-food categories are only a subset of the total expenditure incurred.

[2] Food expenditure includes spending on Rice, Wheat, Sugar, Other cereals, Cereal products, Pulses, Meat, Sweeteners, Edible oil, Eggs, Milk, Milk products, Vegetables, Fruits/nuts, Salt/spices and Other food.

[3] Non-food expenditure includes Paan/tobacco/intoxicants, Restaurants/Eating out, Entertainment, Telephone/Cable/Internet charges, Toiletries, Transportation, Consumer taxes/fees, Services (domestic servants, barber, laundry, etc.) and Medical (out-patient services)

[4] The assets index used here remains the same for 2004-5 and 2011-12. The assets include any vehicle, Sewing machine, Mixer/grinder, Motor vehicle, any TV, Colour TV, Air cooler/cond, Clock/watch, Electric fan, Chair/table, Cot, Telephone, Cell phone, Refrigerator, Pressure cooker, Car, Air conditioner, Washing machine, Computer, Credit card, 2 clothes, Footwear, Piped indoor water, Separate kitchen, Flush toilet, Electricity, LPG, Pucca wall, Pucca roof and Pucca floor.

[5] We have used the variable on household poverty as defined by IHDS. 2005. See Endnote12for its definition.

[6] IHDS has enquired about different sources of income. The total income variable is calculated from the income in farms, agricultural wages, non-agricultural sources, salary, business, remittances, government benefits and other sources. We have deducted the payment received from IGNOAPS from this.

[7] Other welfare programs include Widow Benefits, Disability benefits, Annapurna benefits, other income benefits, NGO benefits and Maternity benefits.

Source: Authors' estimations based on IHDS data. 
Appendix 3: Results of Probit Model on whether a household received IGNOAPS in PSM

\begin{tabular}{|c|c|c|}
\hline Variables & $\begin{array}{c}2004-5 \\
\text { Coefficients } \\
\end{array}$ & $\begin{array}{c}\text { 2011-12 } \\
\text { Coefficients } \\
\end{array}$ \\
\hline BPL card & $\begin{array}{l}0.180^{\star * *} \\
(0.03)\end{array}$ & \\
\hline Antyodaya card & $\begin{array}{l}0.508^{* * *} \\
(0.07)\end{array}$ & \\
\hline Household: elderly & $\begin{array}{l}1.524^{\star * *} \\
(0.04)\end{array}$ & $\begin{array}{l}1.625^{\star * *} \\
(0.027)\end{array}$ \\
\hline Rural area \& attends public meeting & $\begin{array}{l}0.077^{\star} \\
(0.03)\end{array}$ & $\begin{array}{l}0.136^{\star * *} \\
(0.022)\end{array}$ \\
\hline Highest education in the household & $\begin{array}{l}-0.030^{* * *} \\
(0.00)\end{array}$ & $\begin{array}{l}-0.025^{\star \star *} \\
(0.002)\end{array}$ \\
\hline Scheduled caste or tribe & $\begin{array}{l}0.239^{\star * *} \\
(0.03)\end{array}$ & $\begin{array}{l}0.107^{\star * *} \\
(0.022)\end{array}$ \\
\hline Women: T.V & & $\begin{array}{l}-0.047 \\
(0.025)\end{array}$ \\
\hline $\begin{array}{l}\text { Household has a BPL or Antyodaya } \\
\text { card }\end{array}$ & & $\begin{array}{l}0.589^{* * *} \\
(0.021)\end{array}$ \\
\hline constant & $\begin{array}{l}-2.83^{\star \star \star} \\
(0.049)\end{array}$ & $\begin{array}{l}-2.515^{\star * \star} \\
(0.037)\end{array}$ \\
\hline Pseudo R2 & 0.23 & 0.27 \\
\hline Number of observations & 41499 & 42141 \\
\hline
\end{tabular}




\section{Appendix 4: A full set of results of PS weighted FE model for matched panel}

\begin{tabular}{|c|c|c|c|c|c|c|c|}
\hline Variables & $\begin{array}{l}\text { Log real } \\
\text { MPCE }\end{array}$ & $\begin{array}{l}\text { Log real } \\
\text { MPCE (food) }\end{array}$ & $\begin{array}{l}\text { Log real } \\
\text { MPCE(non- } \\
\text { food) }\end{array}$ & $\begin{array}{l}\text { Log assets } \\
\text { index }\end{array}$ & $\begin{array}{l}\text { Log } \\
\text { number of } \\
\text { household } \\
\text { members } \\
\text { working }\end{array}$ & Poor & $\begin{array}{l}\text { Log of } \\
\text { household } \\
\text { income } \\
\text { minus } \\
\text { IGNOAPS }\end{array}$ \\
\hline 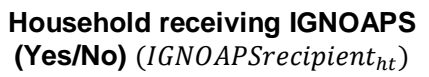 & $\begin{array}{l}0.0549^{* *} \\
(0.01)\end{array}$ & $\begin{array}{l}0.0575^{\star \star *} \\
(0.01)\end{array}$ & $\begin{array}{l}0.0874^{* *} \\
(0.03)\end{array}$ & $\begin{array}{l}0.100^{* * *} \\
(0.01)\end{array}$ & $\begin{array}{l}-0.0992^{\star \star \star} \\
(0.01)\end{array}$ & $\begin{array}{l}0.0124 \\
(0.01)\end{array}$ & $\begin{array}{l}-0.0119 \\
(0.03)\end{array}$ \\
\hline \multicolumn{8}{|l|}{ Control variables } \\
\hline $\begin{array}{l}\text { Household size excl. children } \\
\text { and elderly }\end{array}$ & $\begin{array}{l}-0.0540^{* * *} \\
(0.00)\end{array}$ & $\begin{array}{l}-0.0654^{* * *} \\
(0.00)\end{array}$ & $\begin{array}{l}-0.101^{* * *} \\
(0.00)\end{array}$ & $\begin{array}{l}0.0169^{* * *} \\
(0.00)\end{array}$ & $\begin{array}{l}0.166^{* * *} \\
(0.00)\end{array}$ & $\begin{array}{l}0.0215^{\star \star *} \\
(0.00)\end{array}$ & $\begin{array}{l}0.142^{* * *} \\
(0.00)\end{array}$ \\
\hline Number of children & $\begin{array}{c}-0.113^{\star * *} \\
(0.00)\end{array}$ & $\begin{array}{l}-0.0934^{* * *} \\
(0.00)\end{array}$ & $\begin{array}{l}-0.142^{* * *} \\
(0.00)\end{array}$ & $\begin{array}{l}-0.0170 * * * \\
(0.00)\end{array}$ & $\begin{array}{l}0.0551^{* * *} \\
(0.00)\end{array}$ & $\begin{array}{c}0.0486^{\star \star *} \\
(0.00)\end{array}$ & $\begin{array}{l}0.0300^{* * *} \\
(0.00)\end{array}$ \\
\hline Number of elderly male & $\begin{array}{c}-0.142^{* * *} \\
(0.02)\end{array}$ & $\begin{array}{c}-0.139^{* * *} \\
(0.01)\end{array}$ & $\begin{array}{c}-0.176^{* * *} \\
(0.03)\end{array}$ & $\begin{array}{c}-0.0534^{\star \star *} \\
(0.01)\end{array}$ & $\begin{array}{l}0.194^{* * *} \\
(0.01)\end{array}$ & $\begin{array}{c}0.0119 \\
(0.01)\end{array}$ & $\begin{array}{c}0.0728^{*} \\
(0.03)\end{array}$ \\
\hline Number of elderly female & $\begin{array}{c}-0.0424^{*} \\
(0.01)\end{array}$ & $\begin{array}{l}-0.0768^{* * *} \\
(0.01)\end{array}$ & $\begin{array}{c}-0.0052 \\
(0.02)\end{array}$ & $\begin{array}{l}0.0820^{* * *} \\
(0.01)\end{array}$ & $\begin{array}{l}0.0477^{* *} \\
(0.01)\end{array}$ & $\begin{array}{l}0.0498^{* * *} \\
(0.01)\end{array}$ & $\begin{array}{c}0.107^{\star * *} \\
(0.02)\end{array}$ \\
\hline $\begin{array}{l}\text { Highest education in the } \\
\text { household }\end{array}$ & $\begin{array}{l}0.0176^{* * *} \\
(0.00)\end{array}$ & $\begin{array}{l}0.00873^{\star * *} \\
(0.00)\end{array}$ & $\begin{array}{l}0.0246^{* * *} \\
(0.00)\end{array}$ & $\begin{array}{c}0.0262^{* * *} \\
(0.00)\end{array}$ & $\begin{array}{l}0.00105 \\
(0.00)\end{array}$ & $\begin{array}{c}-0.00460^{*} \\
(0.00)\end{array}$ & $\begin{array}{l}0.0378^{* * *} \\
(0.00)\end{array}$ \\
\hline Urban area & $\begin{array}{l}0.239^{* * *} \\
(0.06)\end{array}$ & $\begin{array}{l}0.173^{* * *} \\
(0.04)\end{array}$ & $\begin{array}{l}0.471^{* * *} \\
(0.09)\end{array}$ & $\begin{array}{l}0.145^{\star * \star} \\
(0.03)\end{array}$ & $\begin{array}{l}-0.033 \\
(0.05)\end{array}$ & $\begin{array}{c}0.0691 \\
(0.05)\end{array}$ & $\begin{array}{l}0.265^{\star} \\
(0.11)\end{array}$ \\
\hline Women: newspaper & $\begin{array}{c}0.0474^{*} \\
(0.02)\end{array}$ & $\begin{array}{c}0.0375^{\star} \\
(0.01)\end{array}$ & $\begin{array}{l}0.0995^{\star * *} \\
(0.03)\end{array}$ & $\begin{array}{c}-0.00329 \\
(0.01)\end{array}$ & $\begin{array}{c}-0.0362 \\
(0.02)\end{array}$ & $\begin{array}{c}-0.0166 \\
(0.01)\end{array}$ & $\begin{array}{c}0.0902^{* *} \\
(0.03)\end{array}$ \\
\hline Women: TV & $\begin{array}{c}0.135^{\star * *} \\
(0.01)\end{array}$ & $\begin{array}{c}0.0880^{* \star *} \\
(0.01)\end{array}$ & $\begin{array}{c}0.221^{* * *} \\
(0.02)\end{array}$ & $\begin{array}{c}0.283^{\star * \star} \\
(0.01)\end{array}$ & $\begin{array}{c}-0.0531^{\star *} \\
(0.01)\end{array}$ & $\begin{array}{c}-0.0499^{* \star *} \\
(0.01)\end{array}$ & $\begin{array}{c}0.174^{* * *} \\
(0.03)\end{array}$ \\
\hline $\begin{array}{l}\text { Number of other welfare } \\
\text { programs received by the } \\
\text { household }\end{array}$ & $\begin{array}{c}0.0808^{\star \star \star} \\
(0.01)\end{array}$ & $\begin{array}{c}0.0488^{* *} \\
(0.01)\end{array}$ & $\begin{array}{c}0.196^{\star \star *} \\
(0.03)\end{array}$ & $\begin{array}{c}0.0921^{* * *} \\
(0.01)\end{array}$ & $\begin{array}{c}-0.0533^{\star *} \\
(0.01)\end{array}$ & $\begin{array}{c}-0.0366^{*} \\
(0.01)\end{array}$ & $\begin{array}{c}0.120^{* * *} \\
(0.03)\end{array}$ \\
\hline Hindu & $\begin{array}{c}0.00745 \\
(0.04)\end{array}$ & $\begin{array}{c}0.00557 \\
(0.042)\end{array}$ & $\begin{array}{l}0.019 \\
(0.07)\end{array}$ & $\begin{array}{c}0.116^{\star *} \\
(0.04)\end{array}$ & $\begin{array}{c}-0.0385 \\
(0.04)\end{array}$ & $\begin{array}{l}0.059 \\
(0.04)\end{array}$ & $\begin{array}{l}0.105 \\
(0.08)\end{array}$ \\
\hline Constant & $\begin{array}{c}6.673^{* * *} \\
(0.05)\end{array}$ & $\begin{array}{c}6.044^{* * *} \\
(0.04)\end{array}$ & $\begin{array}{c}5.192^{* * *} \\
(0.08)\end{array}$ & $\begin{array}{c}1.770^{\star * *} \\
(0.04)\end{array}$ & $\begin{array}{c}0.132^{\star *} \\
(0.04)\end{array}$ & $\begin{array}{c}0.0627 \\
(0.04)\end{array}$ & $\begin{array}{c}9.231^{* * *} \\
(0.09)\end{array}$ \\
\hline Observations & 76536 & 76518 & 76448 & 76499 & 72186 & 76562 & 75233 \\
\hline F-stat & 81.14 & 90.91 & 81.29 & 87.33 & 161.8 & 20.37 & 55.61 \\
\hline R-squared & 0.888 & 0.886 & 0.85 & 0.932 & 0.897 & 0.843 & 0.897 \\
\hline
\end{tabular}

Notes: Robust standard errors in parentheses; ${ }^{*} p<0.05,{ }^{* *} p<0.01,{ }^{* \star *} p<0.001$; Source: Authors' estimations based on IHDS data. 


\section{Endnotes}

${ }^{1}$ http://datatopics.worldbank.org/aspire/country/india

${ }^{2}$ A report by the Ministry of Statistics points out that between 2001 and 2011 there was a $35 \%$ increase in the number of persons who are 60 years of age or above in India (GoI, 2016). ${ }^{3}$ For the convenience, we call the programme IGNOAPS in both 2004-5 and 2011-12 in the empirical section.

${ }^{4}$ Retrieved from the Government of India website, http://nsap.nic.in/ on National Social Assistance Programme.

${ }^{5}$ https://data.gov.in/catalog/expenditure-and-beneficiaries-under-nsap

${ }^{6} \mathrm{https} / / /$ data.gov.in/resources/physical-and-financial-progress-nsap-components

${ }^{7}$ At the individual level, $10 \%$ of the IGNOAPS recipients receive the program in both time periods, and $75 \%$ of the beneficiaries received the program only in 2011 . The average annual amount received by beneficiaries is INR 4107 in 2011, compared to INR 1818 in 2005.

${ }^{8}$ It is noted that replacing the explanatory variable on age criteria in the probit model by ' 65 years or above' will not change the results in the first and second stages. It should also be noted that the definition of the elderly varied across states depending on gender, especially in 20045 (Kaushal, 2014). As a further robustness check, we used the lowest age eligibility criteria which Rajasthan used (55 years for female and 58 years for male). Final results of the impact estimates are broadly same regardless of the age thresholds in deriving PS.

${ }^{9}$ For PSM the assumption for the balancing property is satisfied in both rounds where the tests are carried out for 10 blocks at different distributional points defined by the estimated PS (Leuven and Sianesi, 2003). We have also carried out the balancing tests based on Rubin (2001) and found that the covariates are strongly balanced with Rubin's B 5.2 (or 3.2) and Rubin's R 
1.02 (or 1.02) for 2004-5 (2011-12) well within the rule of thumb (Rubins-B<25, Rubins-R $[0.5 ; 2])$.

${ }^{10}$ The method of matching has been increasingly used in program evaluation mechanism (e.g. Dabalen et al., 2008) to construct a valid counterfactual group, whilst the method of fixed effects is also used to study the impact of social policies (Ardington, et al., 2009; Abel, 2019) to eliminate unobserved time-invariant heterogeneities.

${ }^{11}$ The choice of the fixed effects model over the random effects model is supported by the Hausman test results in all the cases we report in this paper.

${ }^{12}$ Poverty is a binary variable defined by IHDS indicating whether the household's monthly consumption per capita is below the Tendulkar poverty line in 2011-12 rounds and the official Planning Commission poverty line in 2004-2005.

${ }^{13}$ An alternative to this method is an instrumental variable (IV) regression where IGNOAPS recipient $_{h t}$ is estimated by an instrumental variable that reflects the household inventive to participate in the programme, but not an outcome variable, but it is difficult to find a valid instrument. We have used 'the number of beneficiaries receiving the program at the village/Urban Local Body level' as an instrument and obtained broadly similar results. However, a question on validity of IV remains and thus we have adopted our methodology described in the text.

${ }^{14}$ The limitations include that (i) we assume that the household unobservable characteristics is fixed and (ii) unlike a (random effects) IV regression with a time-varying IV, we take into account a differential incentive to participate in the programme in 2004-5 and 2011-12 only indirectly by weighting the regression by the probability of non-participating households joining the programme.

${ }^{15}$ The PS weighted regression approach can also reduce any bias in our impact estimates arising from the fact that different states may adopt different eligibility criteria, such as age (Appendix 
1). Our study does not involve any explicit measurement errors in treatment, but can be justified by Babanezhad et al. (2010) which showed that, if treatments are misclassified and the misclassification is correlated with confounders, the bias in the estimate of the PS adjusted regression is likely to be smaller than OLS or other models as the bias of the former is independent of the treatment-confounder association.

${ }^{16}$ Validation of DID results requires the parallel trend assumption which stipulates that the difference of the outcome variables are same for the treatment and control groups over time. This requires at least three points of time of the data, including the baseline where neither groups was treated. In our case as we do not have the pre-intervention data, it is impossible to test this assumption. However, the data context where the control and treatment households are scattered in every village across all the states in India would justify our use of DID as both groups are on average likely to show similar trends. Simulation data by Ryan et al. (2019) highlight that the DID estimates performed on the matched sample is not sensitive to the violation of parallel trend assumption.

${ }^{17}$ new IGNOAPS recipient is equivalent to the interaction of the (time-invariant) treatment dummy variable (whether the household has ever been treated) and the time-dummy variable. The fixed-effects $\left(\mu_{h}\right)$ capture the treatment dummy.

${ }^{18}$ To see whether the amount (annual) of money received by the household influences outcome variable, we have replaced the primary explanatory variable in Equation (1) by the annual amount of money received by the household. We have found the results broadly consistent with Table 2 that a $10 \%$ increase in IGNOAPS payment at its mean leads to an increase of monthly expenditure by $0.03 \%$; food (non-food) per capita expenditure by $0.04 \%$ (0.05\%): household assets increase by $0.07 \%$, the number of household members worked reduces by $0.07 \%$. The impacts on poverty and income are statistically non-significant. The marginal increase in the IGNOAPS payment leads to relatively small increases in outcome variables given that (i) it is 
a marginal effect of an additional IGNOAPS payment evaluated at its mean of all the sample and (ii) the IGNOAPS payment is relatively small than the total income or consumption.

${ }^{19}$ Despite the average increase in consumption expenditure at mean (the second column), poverty increased, suggesting that consumption increase is not uniform across different levels of consumption and decreases around the poverty threshold when female members are the recipients. This may be due to the fact that a significant share of non-poor households participated in IGNOAPS.

${ }^{20} \mathrm{We}$ estimated the effect of IGNOAPS on the asset outcome variable when the program is accessed by non-poor households (above poverty line) based on the FE and DID models. The effects on assets are positive and statistically significant in the FE model (by 6.3\%) and positive but not statistically significant in the DID model (2.9\%).

${ }^{21}$ The DID estimates for various sub-samples (as in Table 3) are broadly consistent with those in Table 4. As a result of the programme expansion, (i) 'elderly labour supply' declined significantly (by 7.9\%), (ii) the labour supply is significantly reduced for households with male recipients $(6.2 \%)$, (iii) assets increased significantly for male, female and scheduled caste/ tribe sub-samples (4.7\% and 6.7\%, 6.8\% respectively) and (iv) household income excluding IGNOAPS declined significantly for scheduled caste/tribe households (18\%) and for the households with male recipients (13\%). Political connections do not matter. The results will be provided upon request.

${ }^{22}$ We have estimated OLS with PS weighting for the matched (cross-sectional) data in 2004-5 and 2011-12 separately and have found statistically significant results on the household welfare improvement only for 2004-5. However, these results should be interpreted with caution as they are subject the bias as the unobservable household fixed effects are not taken into account. 